\title{
Population genetic structure and connectivity of a riparian selfing herb Caulokaempferia coenobialis at a fine-scale geographic level in subtropical monsoon forest
}

\author{
Qiong Fu ${ }^{1 \dagger}$, Jie Deng ${ }^{1 \dagger}$, Min Chen ${ }^{1 \dagger}$, Yan Zhong ${ }^{1}$, Guo-Hui Lu ${ }^{1}$ and Ying-Qiang Wang ${ }^{1,2^{*}}$ (D)
}

\begin{abstract}
Background: Rivers and streams facilitate movement of individuals and their genes across the landscape and are generally recognized as dispersal corridors for riparian plants. Nevertheless, some authors have reported directly contrasting results, which may be attributed to a complex mixture of factors, such as the mating system and dispersal mechanisms of propagules (seed and pollen), that make it difficult to predict the genetic diversity and population structure of riparian species. Here, we investigated a riparian self-fertilizing herb Caulokaempferia coenobialis, which does not use anemochory or zoochory for seed dispersal; such studies could contribute to an improved understanding of the effect of rivers or streams on population genetic diversity and structure in riparian plants. Using polymorphic ISSR and cpDNA loci, we studied the effect at a microgeographic scale of different stream systems (a linear stream, a dendritic stream, and complex transverse hydrological system) in subtropical monsoon forest on the genetic structure and connectivity of C. coenobialis populations across Dinghu Mountain (DH) and Nankun Mountain (NK).

Results: The results indicate that the most recent haplotypes ( $\mathrm{DH}: \mathrm{H7}$, H8; NK: h6, h7, h11, h12) are not shared among local populations of $C$. coenobialis within each stream system. Furthermore, downstream local populations do not accumulate genetic diversity, whether in the linear streamside local populations across DH (H: 0.091 vs 0.136$)$ or the dendritic streamside local populations across NK ( $H: 0.079$ vs $0.112,0.110$ ). Our results show that the connectivity of local C. coenobialis populations across DH and NK can be attributed to historical gene flows, resulting in a lack of spatial genetic structure, despite self-fertilization. Selfing $C$. coenobialis can maintain high genetic diversity $(H=0.251$; $I=0.382)$ through genetic differentiation $\left(G_{S T}=0.5915 ; F_{S T}=0.663\right)$, which is intensified by local adaptation and neutral mutation and/or genetic drift in local populations at a microgeographic scale.
\end{abstract}

Conclusion: We suggest that streams are not acting as corridors for dispersal of C. coenobialis, and conservation strategies for maintaining genetic diversity of selfing species should be focused on the protection of all habitat types, especially isolated fragments in ecosystem processes.

Keywords: Genetic variation, Mating system, Fine-scale spatial genetic structure, Gene flow, Seed dispersal

${ }^{*}$ Correspondence: wangyq@scnu.edu.cn

${ }^{\dagger}$ Qiong Fu, Jie Deng and Min Chen contributed equally to this manuscript.

${ }^{1}$ Guangdong Provincial Key Laboratory of Biotechnology for Plant Development, School of Life Sciences, South China Normal University, Guangzhou, China

Full list of author information is available at the end of the article

\section{Background}

Genetic variation in a plant species is determined by mating system, natural selection, evolutionary history, life-history characteristics, and mechanisms of gene flow (dispersal ability of pollen and seed), and these factors can lead to complex genetic structuring of populations 
within the species $[1,2]$. Therefore, the genetic diversity and structure of plant populations can reveal useful information about, and is regarded as the strategic mainstay of, biodiversity and the diversity of a species within and among wild populations inhabiting an ecosystem [3-5]. The increase in human-mediated disturbance in recent decades, such as the destruction of forests and fragmentation of the habitats of many plant species, has led to a rapid loss of biodiversity and consequent changes in the structure of landscapes [6-8]. Thus, an increased understanding of genetic variation and connectivity in species found in habitats of high natural value is key to the development of conservation strategies for small and isolated populations $[9,10]$. Forests support about $65 \%$ of the world's terrestrial taxa and have the highest species diversity for many taxonomic groups; thus conserving forest biodiversity is a critical task and has rightly become a key component of many national and international forest management agreements [11]. So far, most studies on the genetic variation and population genetic structure of forest plants have focused on woody plants [12-20], while empirical studies on undergrowth herbs are rare [21-26]. Among the latter, studies on riparian plants in the undergrowth (e.g. Primula sieboldii, [22]; Heliconia metallica, [27]), are rarer still.

Rivers or streams facilitate movement of individuals and genes across the landscape and are generally recognized as corridors for riparian plants $[5,28]$. The passive movement of propagules by water (hydrochory) is an important mode of dispersal for riparian plant species, and it has a significant influence on the composition of riparian plant communities, often promoting species richness $[18,29,30]$. The effectiveness of water as a dispersal vector means that hydrochory is also responsible for high levels of gene flow and thus reduces genetic differentiation between populations as well as greater genetic diversity of downstream populations [31-35]. However, some authors report the opposite results, i.e. that both marked genetic differentiation and genetic discontinuity can be found among populations within a river, suggesting that rivers do not act as corridors for dispersal [36-41]. The above contrary results may be attributed to a number of competing factors (e.g. river/ stream, mountains, and fragmentation) that might all be involved to some degree in the historical or current dispersal of seeds or vegetative propagules, leading to difficulty in predicting the genetic diversity and population structure of riparian species [41]. Mountain ridges act as geographical barriers and can hinder gene flow, causing genetic differentiation in plants [42], and habitat fragmentation may disrupt or reduce gene flow and erode genetic variation in plants [43]. Moreover, the breeding system and dispersal ability of pollen and seed, which are the most important factors affecting the spatial genetic structure and dynamics of populations within species [44-46], have not been considered in previous studies on riparian plants. In outcrossing plants, pollen dispersal has the potential for long-distance gene transport by wind or animal pollinators, and thus is generally an important component of total gene flow [47-49]. Previous studies have shown that outcrossing plants can preserve a degree of genetic diversity through frequent gene flow among populations, while genetic differentiation can effectively be eliminated when gene flow per generation is very low $[50,51]$. In contrast, the movement of seeds is the main component of gene flow for selfing plants due to lack of pollen migration among demes of selfing species. Numerous studies on genetic variation have shown that within-population diversity is typically reduced in selfing species relative to outcrossing species, but genetic differentiation among populations is strengthened [52-56]. In fact, the movement of seeds may influence the spatial distribution of genetic diversity and favors genetic connectivity between populations of both selfing and outcrossing plants. Most seeds disperse very close to the source plants, and thus spatial aggregation of seeds with shared lineages is expected in most situations [57]. However, there are several factors, such as hydrochory, anemochory and zoochory, that may influence secondary seed dispersal and alter seed distribution patterns [58-61], which accordingly may influence the spatial distribution of genetic diversity and genetic connectivity between populations. As a result, because of this complex mixture of factors, it can be difficult to fully understand what drives genetic diversity and population structure in riparian plants. Thus, studies of a species with no pollen migration (selfing) and without anemochory or zoochory seed dispersal are needed; such studies could contribute to an improved understanding of the effect of rivers or streams on population genetic diversity and structure in riparian plants. In addition, numerous previous studies on riparian plants were carried out on a macrogeographic scale, with few performed at a finescale geographic level (e.g. Hibiscus moscheutos, [62]; Primula sieboldii, [22]; Mauritia flexuosa, [17]). However, knowledge of the extent to which rivers or streams impact fine-scale population genetic patterns and, in particular, how factors such as the direction of river flow structure populations, is essential for understanding the likely effect of habitat on riparian plants.

Caulokaempferia coenobialis (Hance) K. Larsen (Fig. S1) is a deciduous perennial herb that grows on steep cliffs along streams in shady, humid monsoon forests in south China [63, 64]. The plant is nonclonal and self-fertilizing by sliding pollen [64, 65] and seeds disperse by rain splash [65-67]. Therefore, selfing $C$. 
coenobialis represents a good system with which to investigate the effect of rivers or streams on population genetic diversity and structure in riparian plants, because it can disentangle the relative influences on the genetic structure of pollen migration and secondary seed dispersal by anemochory or zoochory. In this study, we assess the levels of genetic variation and differentiation within and between local populations of selfing C. coenobialis on a microgeographic scale using cPDNA and ISSR (inter-simple sequence repeat) data, focusing on the following questions: (1) does selfing C. coenobialis show low genetic diversity and significant spatial genetic structure on a microgeographic scale, as theory predicts? (2) do streams facilitate the dispersal of $C$. coenobialis seeds among local populations along the longitudinal course of a stream, thus leading to an accumulation of genetic diversity in downstream local populations, as theory predicts?

\section{Results}

\section{ISSR, cpDNA characteristics and genetic diversity}

The ten ISSR primers produced 218 reproducible bands (an average of 21.8 bands per primer) from the 13 local populations in metapopulations $\mathrm{DH}$ and NK, of which $213(97.7 \%)$ were polymorphic and $6(2.8 \%)$ were specific (Table 1, Table 2). At the metapopulation level, the averages of Nei's genetic diversity $(H)$ and the Shannon indices $(I)$ of $C$. coenobialis were 0.251 and 0.382 , respectively. The genetic diversity index of NK was greater than that of DH ( $H: 0.298$ vs $0.204 ; I: 0.450$ vs 0.313 ). At the local population level, genetic diversity index ranged from 0.058 to 0.136 ( $H$, average of 0.098$)$ and 0.089 to $0.211(I$, average of 0.152 ). Local populations JLS (DH) and TYSZ (NK) showed the highest levels of genetic diversity ( $H=0.136, I=0.209 ; H=0.136, I=0.211$, respectively), while local populations FST (DH; $H=0.091, I=0.138$ ) and SLCX (NK; $H=0.058, I=0.089$ ) exhibited the lowest levels. Among all local populations except JLS (DH) and TYSZ (NK), common loci (i.e. found in all individuals/local population: gene frequency $=100 \%$ ) accounted for the highest proportion of amplified fragments (34.3$60.4 \%)$, while low-medium gene frequency loci $(5 \%<$ gene frequency $\leq 50 \%$ ) accounted for a higher proportion of amplified fragments (23.6-41.9\%) than medium-high gene frequency loci $(50 \%<$ gene frequency $<100 \%)(13.2-$ $24.1 \%$ ) (Fig. 1). Rare loci (gene frequency $\leq 5 \%$ ) represented a very low proportion in all 13 local populations (0.0-9.5\%). However, at the metapopulation level, both common loci and rare loci of DH and NK were less prevalent, i.e. $14.2 \%$ and $14.8 \%$, and $4.8 \%$ and $5.8 \%$, respectively, but loci with low-medium and medium-high gene frequency accounted for a higher proportion of amplified fragments, i.e. $37.2 \%$ and $33.9 \%$, and $55.8 \%$ and $33.7 \%$, respectively.

The concatenated and aligned cpDNA sequences for metapopulations DH and NK were a total of 1262 and 1191 base pairs (bp) long, respectively. The polymorphisms identified 20 haplotypes in DH and NK, of which eight haplotypes (H1-H8) resided in $\mathrm{DH}$ and 12 haplotypes (h1-h12) resided in NK (Table 1, Fig. 2). At the metapopulation level, cpDNA data revealed high estimates of the average chlorotype diversity $(h=0.869)$ and average nucleotide diversity $\left(\pi=2.375 \times 10^{-3}\right)$. At the local population level, haplotype diversity and nucleotide diversity ranged from 0 to 0.800 (average 0.489 ) and from 0 to $3.170 \times 10^{-3}$ (average $0.845 \times 10^{-3}$ ), respectively. All local populations except SH and XXPB (NK) were polymorphic, while local populations JLS (DH) and SLCX (NK) contained four and three different haplotypes, respectively.

\section{Genetic differentiation and gene flow}

Based on the ISSR dataset (Table 3), the genetic differentiation value $\left(G_{\mathrm{ST}}\right)$ for the local populations of $C$. coenobialis in DH and NK was 0.5034 and 0.6796 , respectively, which indicates that $49.66 \%$ and $32.04 \%$ of total genetic variability was distributed within local populations in $\mathrm{DH}$ and $\mathrm{NK}$, respectively. The estimated gene flow $(\mathrm{Nm})$ per generation among local populations in DH and NK was 0.4933 and 0.2357 , respectively. In NK, the genetic differentiation among the transverse hydrological system local populations in NK-II were greater than among the dendritic streamside system local populations in NK-I $\left(G_{\mathrm{ST}}\right.$ : 0.6589 vs 0.5982$)$; accordingly, the mean estimated gene flow $(\mathrm{Nm})$ among local populations in NK-II is lower than that in NK-I (0.2588 vs 0.3359$)$. AMOVA results (Table 4) were consistent with the Nei's genetic differentiation statistics, showing that $53.00 \%$ and $69.00 \%$ of the total variation was partitioned among local populations of DH and NK, respectively. In NK, $63.00 \%$ and $71.00 \%$ of the total variation was partitioned among local populations in NK-I and NK-II, respectively.

For cpDNA, the coefficient of genetic differentiation $\left(F_{\mathrm{ST}}\right)$ among local populations was estimated as 0.556 and 0.770 for DH and NK, respectively (Table 3 ). The $\mathrm{Nm}$ per generation among local populations in $\mathrm{DH}$ and NK was 0.40 and 0.14 , respectively. In NK, the $F_{\mathrm{ST}}$ among NK-II local populations was lower than that among NK-I local populations $(0.477$ vs 0.863$)$. AMOVA (Table 4$)$ revealed that the molecular variance was partitioned among local populations both in DH (54.63\%) and NK (84.55\%). However, $86.5 \%$ of the total molecular variance resided among local populations in NK-I, while $47.67 \%$ of the total molecular variance was attributable to the divergence among local populations in NK-II. 


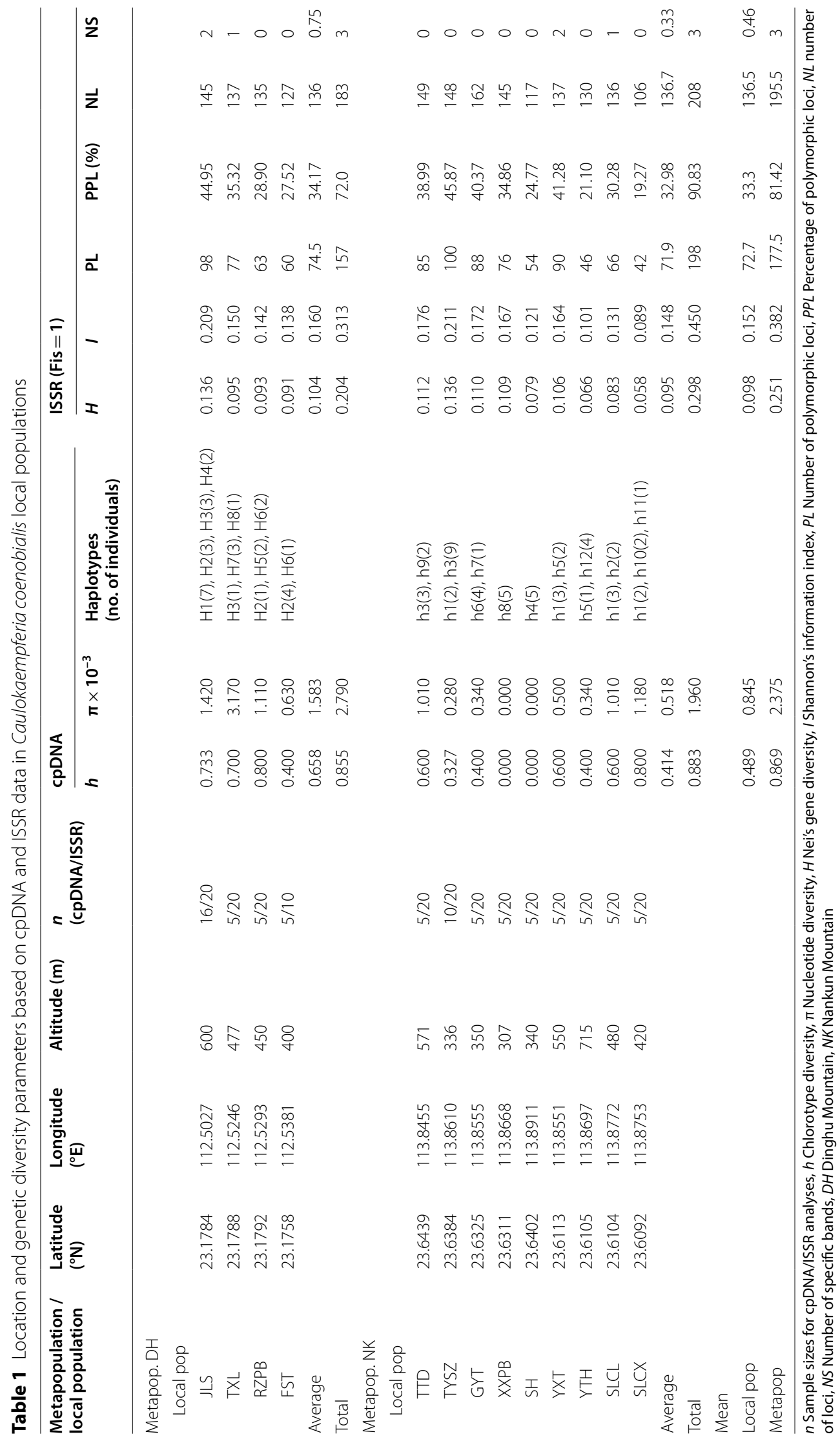


Table 2 Attributes of two cpDNA and ten ISSR primers used in the present study

\begin{tabular}{|c|c|c|c|c|c|}
\hline Primer & Sequence $5^{\prime}$ to $3^{\prime}$ & $\begin{array}{l}T /{ }^{\circ} \mathrm{C} \text { Annealing } \\
\text { temperature }\end{array}$ & SR & NT & NP \\
\hline \multicolumn{6}{|l|}{ cpDNA } \\
\hline \multirow[t]{2}{*}{ trnL intron } & F: CGAAATCGGTAGACGCTACG & 48 & & & \\
\hline & R: GGGGATAGAGGGACTTGAAC & & & & \\
\hline \multirow[t]{2}{*}{ psbJ-petA } & F: ATAGGTACTGTAR*CYGGTATT & 52 & & & \\
\hline & R: AACAR*TTY*GAR*AAGGTTCAATT & & & & \\
\hline \multicolumn{6}{|l|}{ ISSR } \\
\hline 807 & $(\mathrm{AG})_{8} \mathrm{~T}$ & 52 & $230-1500$ & 21 & 20 \\
\hline 808 & $(\mathrm{AG})_{8} \mathrm{C}$ & 52 & $180-1700$ & 20 & 19 \\
\hline 810 & $(G A)_{8} T$ & 52 & $210-1520$ & 22 & 22 \\
\hline 835 & $(\mathrm{AG})_{8} \mathrm{Y}^{*} \mathrm{C}$ & 58 & $170-1700$ & 19 & 17 \\
\hline 836 & $(A G)_{8} Y^{*} A$ & 50 & $250-1700$ & 20 & 20 \\
\hline 840 & $(G A)_{8} Y^{*} T$ & 52 & $200-1500$ & 22 & 22 \\
\hline 841 & $(G A)_{8} Y^{*} C$ & 52 & 180-1780 & 23 & 22 \\
\hline 847 & $(C A)_{8} R^{*} C$ & 52 & $280-1700$ & 24 & 24 \\
\hline 859 & $(\mathrm{TG})_{8} \mathrm{RC}$ & 49 & 290-1700 & 24 & 24 \\
\hline 887 & $\mathrm{DVD}^{*}(\mathrm{TC})_{7}$ & 52 & $220-1700$ & 23 & 23 \\
\hline Total & - & - & - & 218 & 213 \\
\hline
\end{tabular}

${ }^{*} \mathrm{Y}: \mathrm{C} / \mathrm{G}, \mathrm{R}: \mathrm{A} / \mathrm{T}, \mathrm{D}: \mathrm{A} / \mathrm{G} / \mathrm{T}$; SR Size range of amplified fragments, NT Number of total bands, NP Number of polymorphic bands

\section{Relationships of cpDNA haplotypes}

In total, 20 cpDNA haplotypes were identified in DH and NK, and of these 14 were private haplotypes restricted to a single local population. Six haplotypes were shared among local populations, of which $\mathrm{H} 1, \mathrm{H} 2$ and $\mathrm{H} 6$ were shared among DH local populations, and h1, h3 and h5 were shared among NK local populations (Table 1, Fig. 2 B1, B2). Of the latter, h1 was shared between NK-I and NK-II, while h3 and h5 only occurred in NK-I and NK-II, respectively (Fig. $2 \mathrm{~B} 2$ ).

The ML chronogram derived from cpDNA of $C$. coenobialis local populations in DH and NK supported the 20 haplotypes as a monophyletic group with a bootstrap value of $100 \%$, with an estimated crown age of ca. 0.521-0.368 Myr (Fig. 2 C). This monophyletic group was further split into two main lineages: the NK lineage (ML bootstrap support $(\mathrm{BS})=95 \%, \mathrm{PP}=0.96)$ and the $\mathrm{DH}$ lineage (ML $\mathrm{BS}=93 \%, \mathrm{PP}=-)$. The most recent common ancestor of the DH lineage $(0.225-0.159 \mathrm{Myr})$ existed earlier than that of the NK lineage (0.103-0.072 Myr). The divergence time estimates (ca. 0.016-0.011 Myr) suggest that $\mathrm{H} 7$ and $\mathrm{H} 8$ were the most recent haplotypes to arise in DH. The h6, h7, h11 and h12 haplotypes arose most recently in NK, with divergence times of ca. 0.009-0.004 Myr.
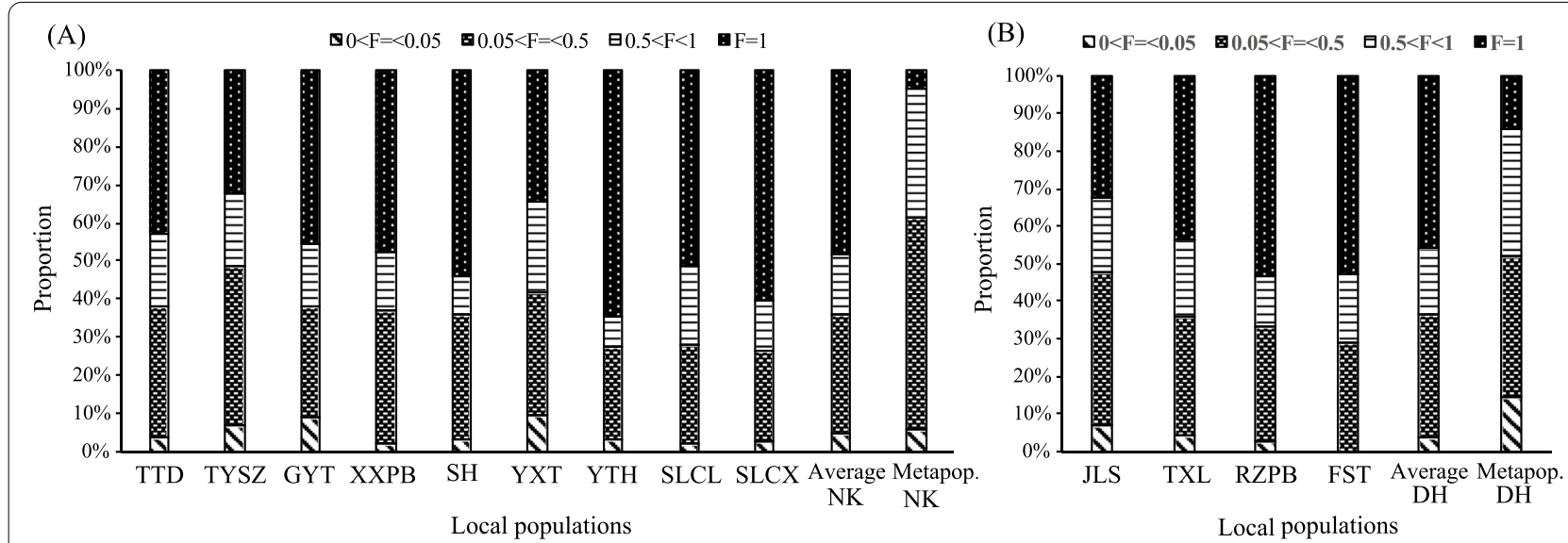

Fig. 1 Distribution of ISSR gene frequency in local populations within metapopulations NK (A) and DH (B) of Caulokaempferia coenobialis 


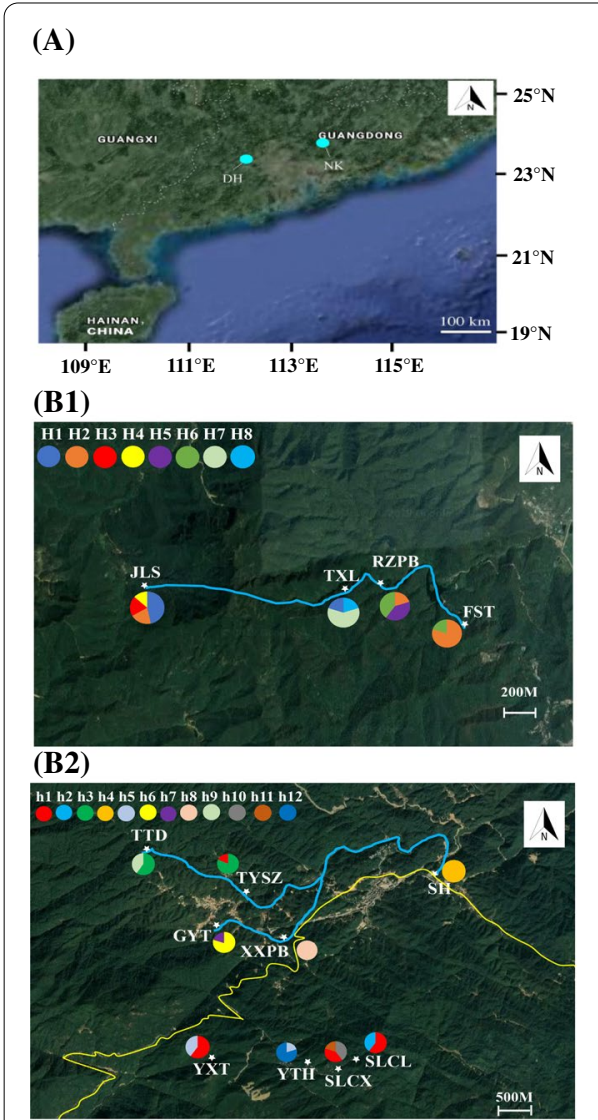

(C)

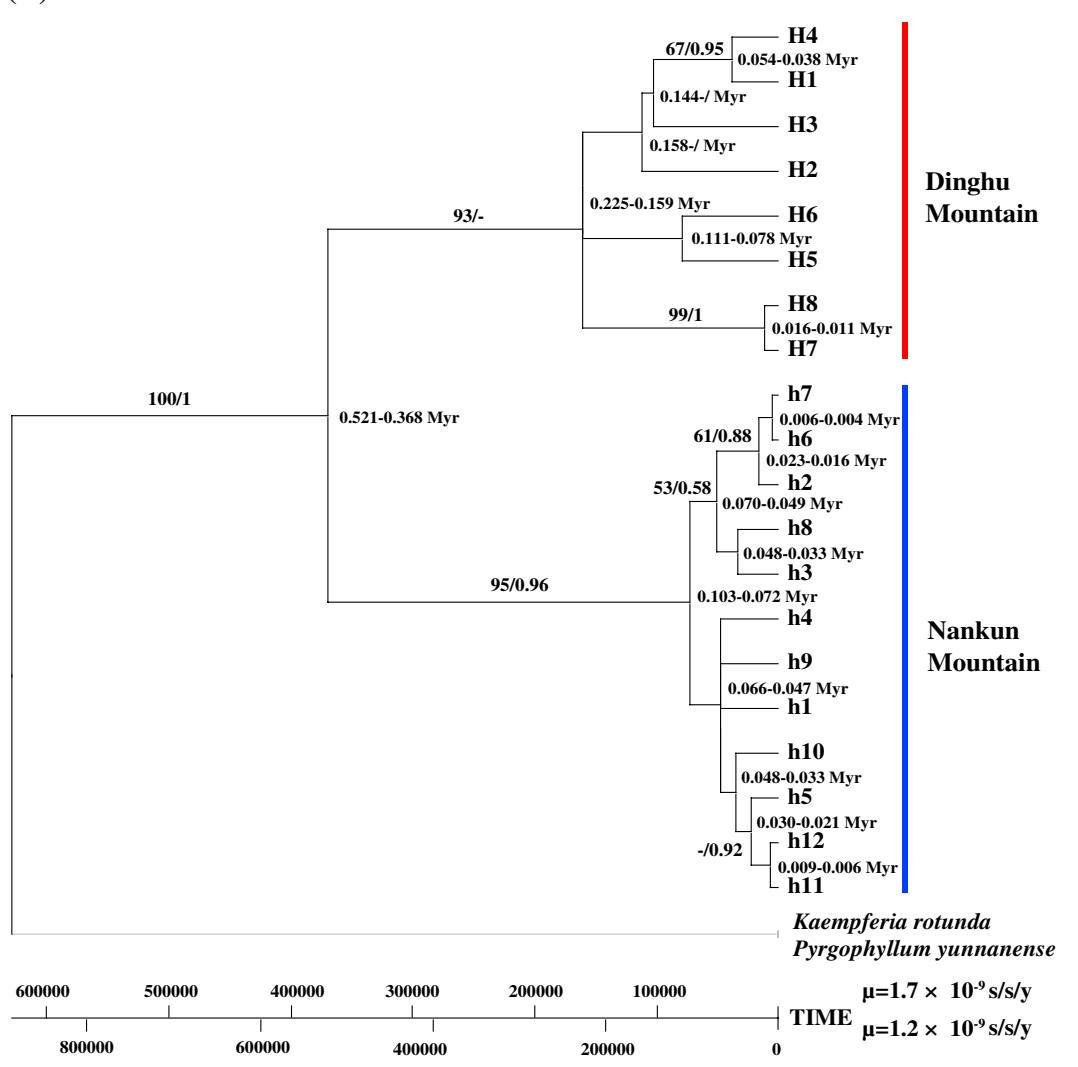

Fig. 2 (A) Location of metapopulations DH and NK; (B) Geographic distribution of the chloroplast (cp) DNA haplotypes of Caulokaempferia coenobialis detected in local populations within metapopulations DH (1) and NK (2). Light blue and yellow lines indicate streams and G355 National Road, respectively; (C) Maximum likelihood (ML) tree of cpDNA haplotypes of C. coenobialis. Bootstrap values (\%) based on ML analysis and posterior probability values (BS/PP) are indicated above/below the branches and the coalescence time for each lineage is indicated at nodes. The original satellite imagery was obtained from Google Map (Map data @2019 Google; https://maps.google.com/) and modified with Adobe Illustrator CS6 (Adobe Systems Incorporated, San Jose, CA, USA)

\section{Genetic clustering and spatial genetic structure within metapopulations}

Bayesian genetic STRUCTURE analyses revealed that the $\log$ likelihood reached a maximum value at $\mathrm{K}=2$ and assigned all local populations to two genetic clusters in DH (Fig. 3 A; Fig. S2 A). In local populations JLS and RZPB, all individuals within each local population were assigned to the same genetic clusters. However, there was a high degree of admixture of two gene pools in all individuals in local populations TXL and FST. In NK, with

Table 3 Statistics for genetic differentiation among local populations of Caulokaempferia coenobialis based on cpDNA and ISSR data $($ Fis $=1)$

\begin{tabular}{|c|c|c|c|c|c|c|c|c|}
\hline \multirow[t]{2}{*}{ Metapopulation } & \multicolumn{4}{|l|}{ cpDNA } & \multicolumn{4}{|l|}{ ISSR } \\
\hline & $H_{\mathrm{T}}$ & Hs & $F_{\mathrm{ST}}$ & $\mathrm{Nm}$ & $\overline{H_{\mathrm{T}}}$ & Hs & $G_{\mathrm{ST}}$ & $\mathrm{Nm}$ \\
\hline Dinghu Mountain & $0.920(0.0672)$ & $0.658(0.0886)$ & $0.556(\mathrm{NC})$ & 0.40 & 0.2088 & 0.1037 & 0.5034 & 0.4933 \\
\hline \multicolumn{9}{|l|}{ Nankun Mountain } \\
\hline All populations & $0.931(0.0332)$ & $0.400(0.0943)$ & $0.770(0.0981)$ & 0.14 & 0.2978 & 0.0954 & 0.6796 & 0.2357 \\
\hline NK-I & $0.896(0.0730)$ & $0.267(0.1229)$ & $0.863(0.0991)$ & 0.07 & 0.2719 & 0.1092 & 0.5982 & 0.3359 \\
\hline NK-II & $0.847(0.0532)$ & $0.600(0.0816)$ & $0.477(0.1552)$ & 0.55 & 0.2291 & 0.0781 & 0.6589 & 0.2588 \\
\hline
\end{tabular}

$H_{\mathrm{T}}$ Total local population diversity, $H_{\mathrm{S}}$ Average within local population diversity, $F_{\mathrm{ST}}$ and $G_{\mathrm{ST}}$ Coefficient of gene differentiation among local populations, $N \mathrm{~m}$ Estimate of gene flow from $G_{S T}, N K-I$ Dendritic streamside system local populations in Nankun Mountain, NK-II Transverse hydrological system local populations in Nankun Mountain 
Table 4 The analysis of molecular variance (AMOVA) for cPDNA data and ISSR data among local populations of Caulokaempferia coenobialis

\begin{tabular}{|c|c|c|c|c|c|c|c|c|c|c|c|}
\hline \multirow[t]{2}{*}{ Metapopulation } & \multirow[t]{2}{*}{ Source of variation } & \multicolumn{5}{|c|}{ cpDNA } & \multicolumn{5}{|c|}{ ISSR } \\
\hline & & d.f & SS & VC & variance (\%) & $R_{\mathrm{ST}}$ & d.f & SS & Est. var & variance (\%) & $\Phi_{\mathrm{ST}}$ \\
\hline \multirow[t]{3}{*}{ Dinghu Mountain } & Among local populations & 3 & 25.967 & 1.1545 & 54.63 & 0.546 & 3 & 747.207 & 13.817 & 53.00 & 0.531 \\
\hline & Within local populations & 26 & 24.933 & 0.9590 & 45.37 & & 66 & 805.450 & 12.204 & 47.00 & \\
\hline & Total & 29 & 50.900 & 2.1135 & 100 & & 69 & 1552.657 & 26.021 & 100 & \\
\hline \multicolumn{12}{|l|}{ Nankun Mountain } \\
\hline \multirow[t]{3}{*}{ All populations } & Among local populations & 7 & 41.659 & 1.1272 & 84.55 & 0.846 & 8 & 3971.111 & 24.272 & 69.00 & 0.689 \\
\hline & Within local populations & 33 & 6.800 & 0.2061 & 15.45 & & 171 & 1872.100 & 10.948 & 31.00 & \\
\hline & Total & 40 & 48.659 & 1.3333 & 100 & & 179 & 5843.211 & 35.220 & 100 & \\
\hline \multirow[t]{3}{*}{ NK-I } & Among local populations & 5 & 29.987 & 1.1279 & 86.50 & 0.865 & 4 & 1772.600 & 21.531 & 63.00 & 0.632 \\
\hline & Within local populations & 25 & 4.400 & 0.1760 & 13.50 & & 95 & 1190.800 & 12.535 & 37.00 & \\
\hline & Total & 30 & 34.387 & 1.3039 & 100 & & 99 & 2963.400 & 34.066 & 100 & \\
\hline \multirow[t]{3}{*}{ NK-II } & Among local populations & 3 & 7.500 & 0.4100 & 47.67 & 0.477 & 3 & 1316.050 & 21.486 & 71.00 & 0.706 \\
\hline & Within local populations & 16 & 7.200 & 0.4500 & 52.33 & & 76 & 681.300 & 8.964 & 29.00 & \\
\hline & Total & 19 & 14.700 & 0.8600 & 100 & & 79 & 1997.350 & 30.450 & 100 & \\
\hline
\end{tabular}

d.f. Degrees of freedom, SS Sum of squares, VC Variance components, Est. var. Estimated variance, $R_{\mathrm{ST}} / \Phi_{\mathrm{ST}}$ Statistics analogous to $F_{\mathrm{ST}}$ statistics; all levels of variation were significant, NK-I Dendritic streamside system local populations in Nankun Mountain, NK-II Transverse hydrological system local populations in Nankun Mountain

$\mathrm{K}=2$ (the second highest $\Delta \mathrm{K}$ value), all local populations were assigned to two genetic clusters (Fig. 3 B; Fig. S2 B), in which almost all individuals were assigned to the same genetic cluster within local populations except for four local populations of NK-I (TTD, TYSZ, GYT, XXPB); this suggests a higher level of admixture of the two gene pools within these four local populations. At the highest log likelihood $(\mathrm{K}=7)$, all local populations in NK could be assigned to seven genetic clusters (Fig. 3 B). Except for three local populations (TYSZ, SH and SLCX), all individuals within each local population showed signs of genetic admixture.

All individuals from the same local populations of $C$. coenobialis in DH and NK were clustered together in the unrooted neighbor-joining (NJ) trees based on ISSR Nei's genetic distance (Fig. 4). In DH, four local populations were classified into two clusters with a similarity index value of $820 / 1,000$ (Fig. 4 A), which comprised two upstream local populations (cluster I: JLS and TXL; highlighted red) and two downstream local populations (cluster II: RZPB and FST; highlighted green), respectively. In NK, nine local populations were grouped into two clusters with a similarity index value of 780/1,000 (Fig. 4 B), of which one cluster (cluster NK-I; highlighted red) comprised the five dendritic streamside system local populations, while the other (cluster NK-II; highlighted green) comprised the four transverse hydrological system local populations, respectively. Cluster NK-I could be divided into two further groups with three clades. One group consisted only of all individuals of local population XXPB, and the other group

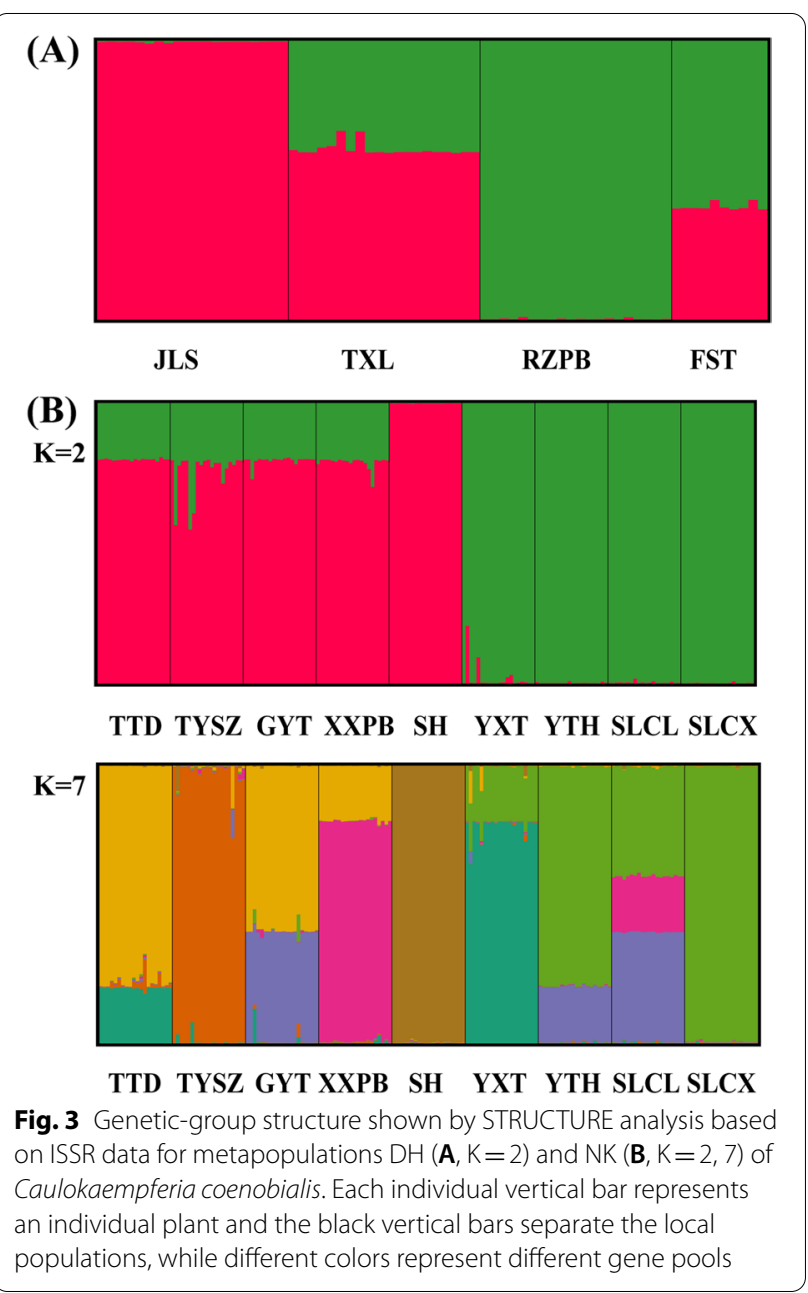




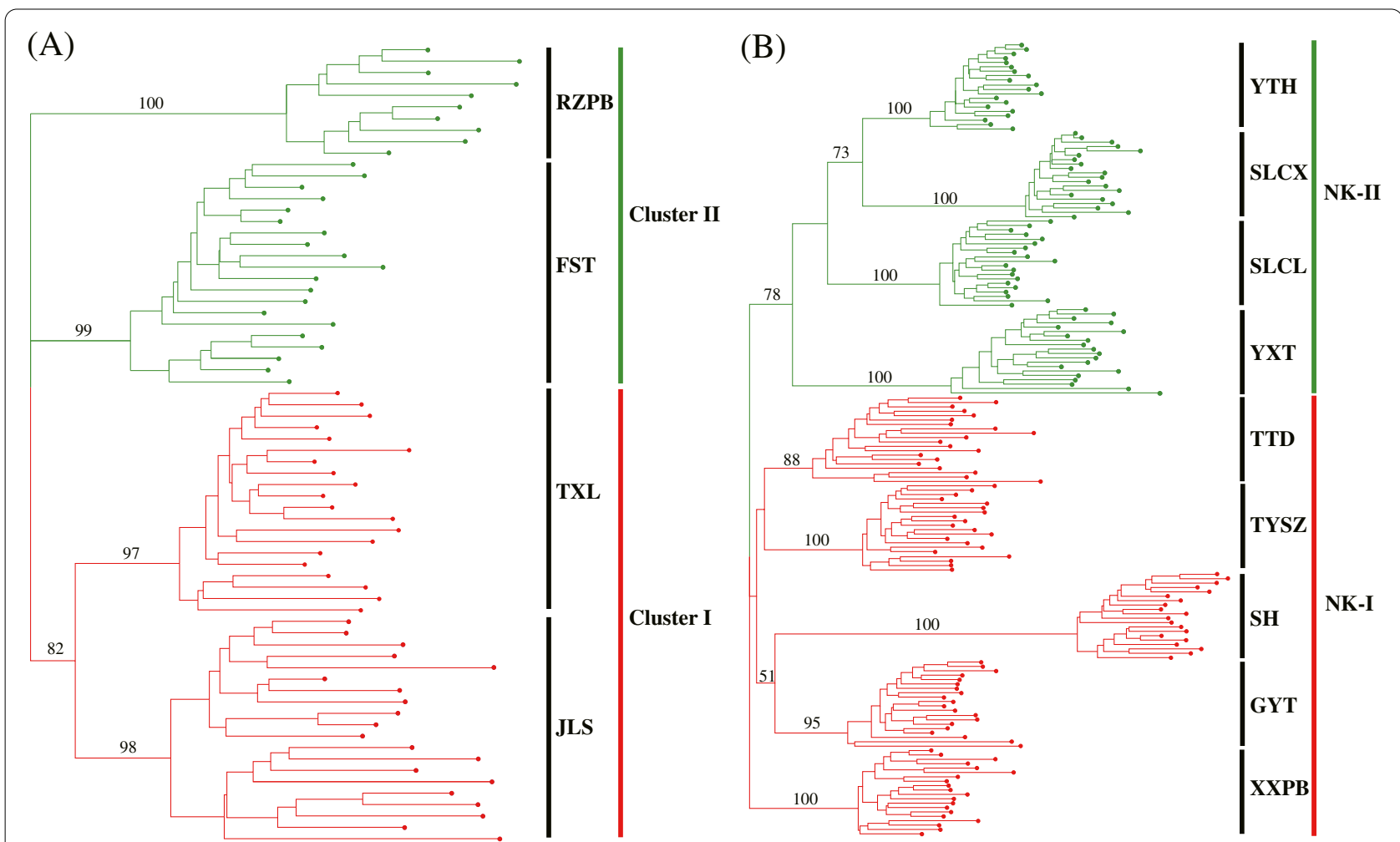

Fig. 4 Unrooted neighbor-joining (NJ) tree based on ISSR Nei's genetic distance for individuals of Caulokaempferia coenobialis within metapopulations $\mathrm{DH}(\mathbf{A})$ and $\mathrm{NK}(\mathbf{B})$. Bootstrap values $(>50 \%)$ are indicated above the branches

consisted of two clades with low bootstrap values, in which local populations GYT and SH formed one clade, and local populations TYSZ and TTD formed the other clade. Similarly, cluster NK-II also formed two groups with three well-resolved clades, of which one group comprised all individuals from local population YXT. The other group consisted of two branches, local population SLCL and another clade including local populations YTH and SLCX. The UPGMA dendrogram (Fig. S3) based on Nei's similarity coefficient also showed that all individuals from the same local populations in DH and NK clustered together. However, the four local populations in $\mathrm{DH}$ were classified into two clusters with three well-resolved clades (Figure S3 A), a result different from that in the $\mathrm{NJ}$ tree. In addition, the nine local populations in NK were separated into two clusters with four clades in the UPGMA dendrogram with a similarity index value of 0.54 (Figure S3 B), a result conflicting with the $\mathrm{NJ}$ tree. The $\mathrm{PCoA}$ analysis (Fig. 5) revealed a pattern that was broadly consistent with the unrooted NJ tree and the genetic-group structure, in which the local populations of $C$. coenobialis in both DH and NK were classified into two clusters, respectively, and all individuals from the same local populations were clustered together.
The Mantel test showed that there was no significant isolation-by-distance relationship across local populations in DH based on both cpDNA $(r=-0.344$, $p=0.423)$ and ISSR $(r=0.007, p=0.428)$ data (Fig. 6 A-1, B-1). However, the genetic divergence of all local populations in NK based on ISSR data was weakly correlated with geographic distance $(r=0.489, p=0.001)$ (Fig. 6 B-2), although no such correlation was observed using cpDNA data $(r=0.262, p=0.152)$ (Fig. 6 A-2). In addition, there was no correlation between genetic and geographical distances among local populations of $C$. coenobialis from either NK-I or NK-II based on cpDNA $(r=0.714, \quad p=0.065 ; \quad r=-0.762, \quad p=0.226$, respectively) or ISSR ( $r=0.818, p=0.097 ; r=0.793, p=0.209$, respectively) data (Fig. 6 A, B). Spatial autocorrelation analysis indicated that significant positive spatial genetic structure was detected at 20-92 cm (Fig. 7).

\section{Discussion}

\section{Can selfing $C$. coenobialis maintain high genetic diversity} on a microgeographic scale?

The mating system is a major factor affecting the genetic variability of plant species. Numerous studies have shown that selfing plant species have less genetic diversity at both the population and species levels than outcrossing 


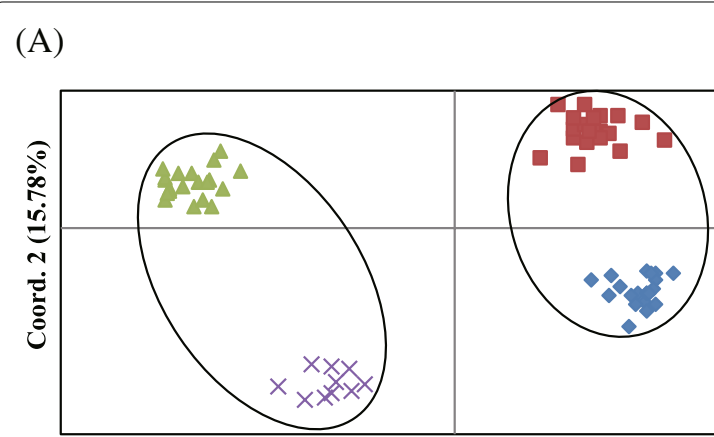

Coord. 1 (20.68\%)
(B)

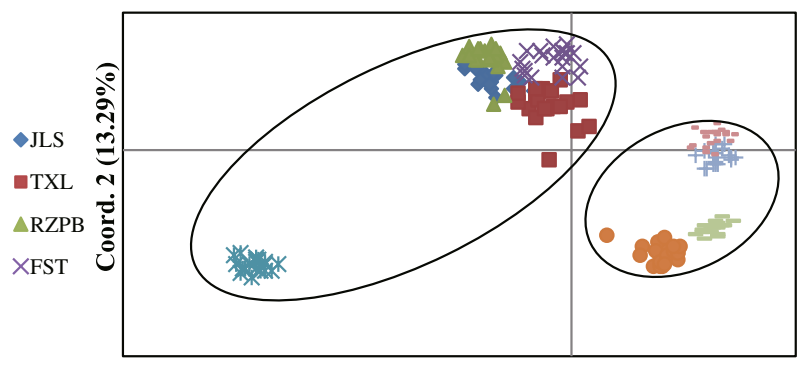

$\bullet$ TTD

-TYSZ

$\triangle \mathrm{GYT}$

ХХXPB

$* \mathrm{SH}$

- YXT

$+\mathrm{YTH}$

-SLCL

- SLCX

Coord. 1 (17.01\%)

Fig. 5 Scatterplot of the principal coordinate analysis (PCOA) based on 218 ISSR genotypes from all sampled individuals in local populations of Caulokaempferia coenobialis in metapopulations DH (A) and NK (B). Different colors represent different local populations

\section{(A-1)}

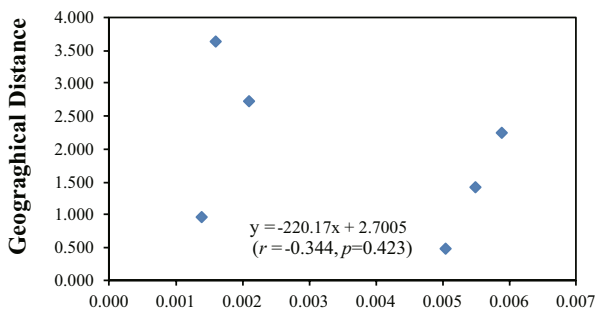

(A-2)

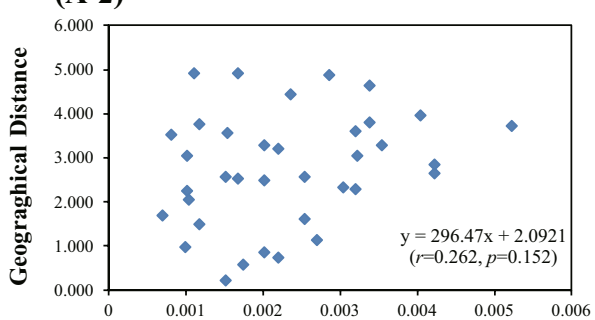

(A-3)

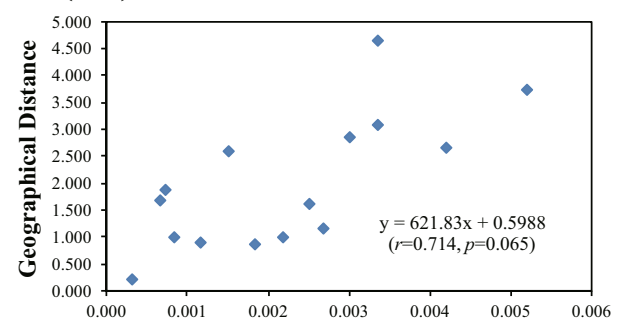

(A-4)

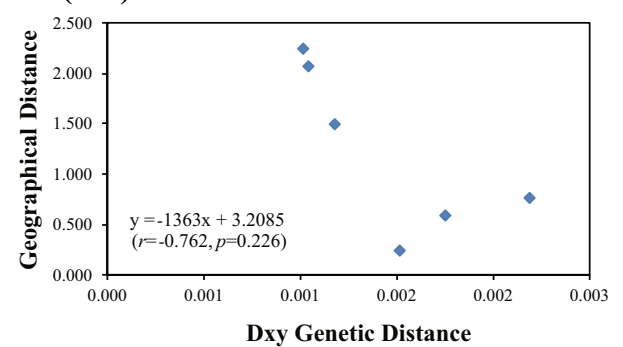

(B-1)

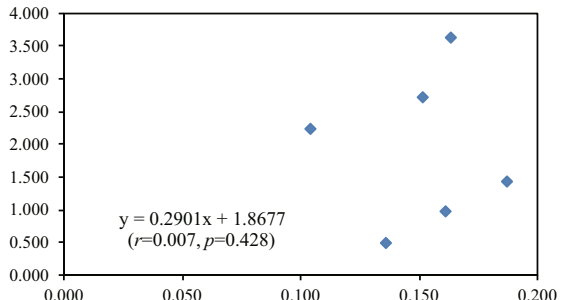

(B-2)

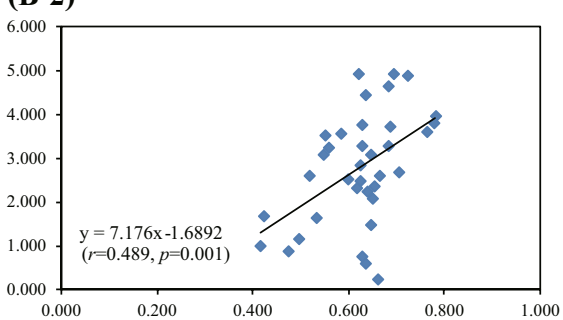

(B-3)

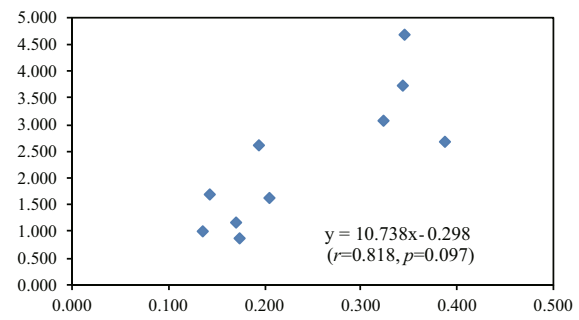

(B-4)

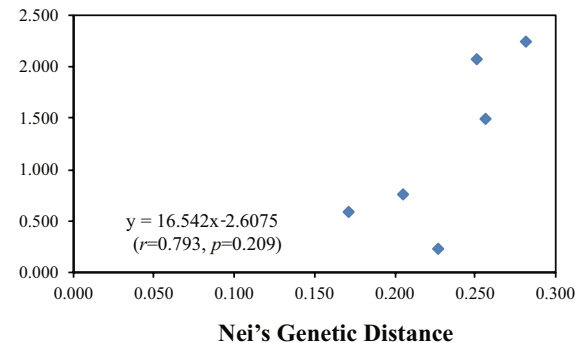

Fig. 6 Plot of Mantel test based on cPDNA data (A) and ISSR data (B) showing the relationships of genetic and geographic distances in local populations of Caulokaempferia coenobialis from metapopulations (1) DH and (2) NK, as well as the two subsets (3) NK-I and (4) NK-II in NK 


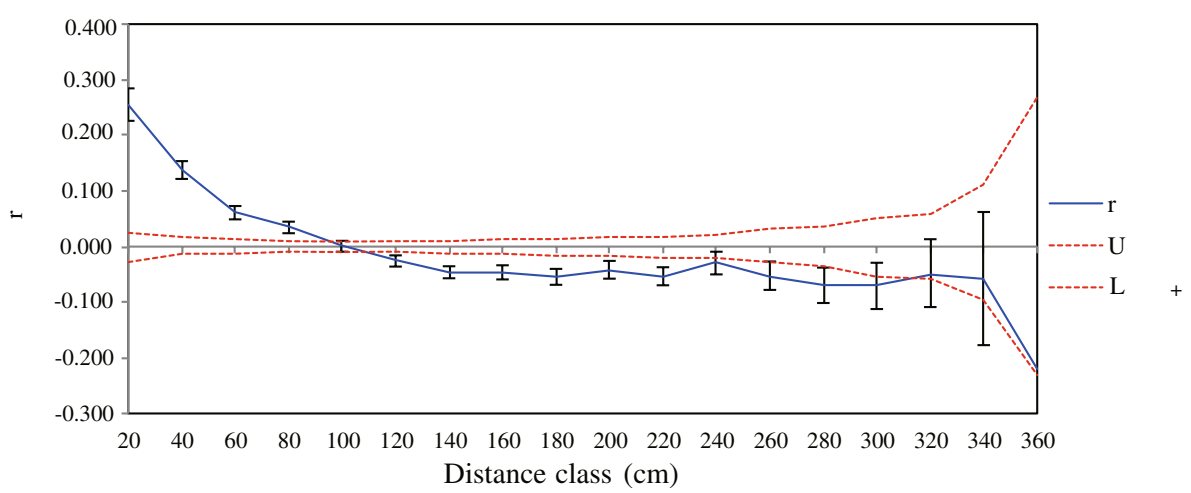

Fig. 7 Correlogram showing the spatial autocorrelation coefficient $r$ within the local population TXL in metapopulation DH of Caulokaempferia coenobialis. $U$ and $\mathrm{L}$ represent the $95 \%$ two-tailed confidence interval, which was calculated based on 999 permutations

species [52, 68-70]. In contrast, comparative studies on two closely related selfing and outcrossing Zingiber species at both the macrogeographic and microgeographic levels $[55,56]$ revealed that, although the level of population/subpopulation genetic diversity in selfing Z. corallinum was significantly lower than that in outcrossing $Z$. nudicarpum, the level of species/metapopulation genetic diversity of selfing $Z$. corallinum was comparable to that of outcrossing $Z$. nudicarpum. Our results are consistent with those of the above comparative study [56], i.e. the level of metapopulation genetic diversity in selfing $C$. coenobialis is comparable to that of outcrossing $Z$. nudicarpum ( $H=0.251$ vs $0.2246, p=0.730 ; I=0.382$ vs $0.3480, p=0.776)$ despite the within-population genetic diversity (Nei's $H=0.098$ ) being significantly lower than that in outcrossing $Z$. nudicarpum $(H=0.098$ vs 0.1464 , $p=0.003 ; I=0.152$ vs $0.2257, p=0.004)$. This implies that, similarly to outcrossing species, selfing plant species can maintain a high level of species genetic diversityalbeit by using different strategies-on both the microgeographic and macrogeographic scales.

Unlike outcrossing species, the high species genetic diversity level of selfing plant species may result from a low pollen migration rate, which leads to high levels of genetic differentiation among populations [71, 72]. Without migration among demes of local populations in selfing $C$. coenobialis metapopulations, any mutation that arises in a particular local population may fix in that local population and cannot spread to other local populations. The present results based on ISSR and cpDNA data confirmed that the genetic differentiation among local populations was relatively high in both DH $\left(G_{\mathrm{ST}}=0.5034, F_{\mathrm{ST}}=0.556\right)$ and NK $\left(G_{\mathrm{ST}}=0.6796\right.$, $\left.F_{\mathrm{ST}}=0.770\right)$ metapopulations. The proportion of ISSR common loci was highest within local populations of $C$. coenobialis, but common loci and low-to-medium gene frequency loci accounted for the lowest proportion and the highest proportion within metapopulations $\mathrm{DH}$ and NK, respectively (Fig. 1). Together, these results indicate that allelic loci vary substantially among local populations, thus leading to a high level of genetic diversity in selfing C. coenobialis on a microgeographic scale (metapopulations DH and NK). Evolutionary theory predicts that genetic drift will result in substantial local differentiation if $N \mathrm{~m}<1$ [73, 74], since gene flow between populations is limited by the extent of pollen and seed dispersal and is insufficient to counter the effects of random drift $[2,75]$. This is the case for selfing C. coenobialis in our study. The estimates of ISSR gene flow $(\mathrm{Nm})$ between local populations of $\mathrm{C}$. coenobialis in $\mathrm{DH}$ and NK were only 0.4933 and 0.2357 on average $(N \mathrm{~m}<1)$, respectively, which can be attributed to a lack of pollen migration within and among local populations [64, 65], as well as to restricted seed dispersal $[66,67]$, as confirmed by a significant positive autocorrelation of spatial genetic structure being detected at only $0.20-0.92 \mathrm{~m}$ within local populations (Fig. 7). In addition, the large numbers of private cpDNA haplotypes that are derived from ancestral haplotypes (DH: H3, H4, H5, H7, H8; NK: h2, h4, h6-h12) reside in local populations, indicating that the local populations of $C$. coenobialis are highly heterogeneous, thus causing an increase in genetic variation [76]. Based on the above, we suggest that selfing $C$. coenobialis can maintain high genetic diversity through differentiation intensified by local adaptation and neutral mutation and/or by the stochastic force of genetic drift in local populations on a microgeographic scale. Thus, conservation strategies for maintaining and improving genetic diversity in selfing species should be focused on the protection of all habitat types, especially isolated fragments in ecosystem processes. 
Do local populations of $C$. coenobialis show significant spatial genetic structure on a microgeographic scale, like most selfing populations?

Self-fertilizing species, with their reduced genetically effective population size and gene flow processes, should be characterized by strong spatial genetic structure [52, 77-79]. Contrary to expectations, the Mantel tests based on both ISSR and cpDNA data suggested no significant correlation between geographical and genetic distance (ISSR: $r=0.007, p=0.428$; cpDNA: $r=-0.344, p=0.423$ ) among local populations of the DH metapopulation, implying that historical dispersal and/or contemporary gene flow by seed dispersal and pollen movement might occur among local populations [75, 80]. Due to the selffertilization mechanism of $C$. coenobialis and thus lack of pollen migration within and among local populations, together with limited seed dispersal, which was confirmed by the low gene flow $(\mathrm{Nm}=0.4933)$ between local populations of $C$. coenobialis across $\mathrm{DH}$, contemporary gene flow should not occur among local populations. Moreover, our results showed that some ancestral haplotypes (H1, H2, and H6) were shared in DH local populations, but not the most recent haplotypes (H7, H8). This confirmed that historical dispersal, but not contemporary gene flow, has occurred among local populations of $C$. coenobialis across DH.

Similarly, Mantel tests based on cpDNA data showed that there was no significant spatial genetic structure in local populations across NK $(r=0.262, p=0.152)$ and that some ancestral haplotypes (h1, h3, h5) were shared among local populations. These results also indicate that historical dispersal has occurred in local populations across NK. However, a weak relationship between local populations was detected in the ISSR data $(r=0.489, p=0.001)$ and the gene flow was very low $(\mathrm{Nm}=0.2357)$, implying that contemporary gene flow between local populations is limited by restricted seed dispersal and absence of pollen movement [2, 75]. This is confirmed by the lack of pollen migration within and among local populations of C. coenobialis $[64,65]$ and the limited seed dispersal $[66,67]$. Our results also showed a lack of the most recent shared haplotypes (h6, h7, h11, h12) among local populations. Together, these results show that local populations of C. coenobialis across NK may have undergone shrinking and fragmentation relatively recently, and that this was accompanied by a greatly decreased gene flow and increased genetic differentiation among local populations. Numerous studies have shown that fragmentation decreases habitat size and increases habitat isolation of populations in many terrestrial ecosystems, and that this reduces gene flow and genetic variation, while increasing the inter-population genetic divergence of plant populations [81-86]. The present results based on ISSR and cpDNA data also confirmed that genetic differentiation among local populations of C. coenobialis across NK was substantial. In fact, as a result of increasing tourism in the NK region, habitat connectivity among local populations of $C$. coenobialis has been destroyed by roads, farm lands and holiday villages, which have likely hindered propagule dispersal. The cluster and STRUCTURE results reveal a clear pattern of population structure in C. coenobialis, with two clusters corresponding to two areas in NK, the West-North area (cluster NK-I: the dendritic streamside system local populations TTD, TYSZ, GYT, XXPB and $\mathrm{SH}$ ) and the East-South area (cluster NK-II: the transverse hydrological system local populations YXT, YTH, SLCL and SLCX). The two areas are separated by the G355 National Road along a valley. Mantel tests based on cpDNA and ISSR data applied to the two clusters separately suggest that there is no significant correlation between geographical and genetic distance in both the dendritic streamside system local populations (ISSR: $r=0.818, p=0.097$; cpDNA: $r=0.714, p=0.065$ ) and the transverse hydrological system local populations (ISSR: $r=0.793, p=0.209$; cpDNA: $r=0.762$, $p=0.226)$. This is also consistent with historical dispersal (historical gene flows), but not recent gene flow.

From all the above, despite self-fertilization in $C$. coenobialis, we know that the connectivity of local populations across both DH and NK can be attributed to historical gene flows, resulting in a lack of spatial genetic structure on a microgeographic scale. Our results also showed that the shared haplotypes all arose before 0.0158 Myr, between the Holocene and Pleistocene, implying that the historical gene flows among local populations of $C$. coenobialis might have happened before the Holocene in DH and NK, namely in the Pleistocene, and are likely attributable to the influence of neotectonic activity in this era. Geological studies $[87,88]$ have shown that, as a result of neotectonic activity in the Pleistocene, the region of the Earth's crust that included Dinghu Mountain and Nankun Mountain was lifted up intermittently, and that this was accompanied by the formation of steep terrain and deep-cut valleys in mountainous areas, the exposure of the bedrock in the valley floor, and the development of complex hydrological systems.

\section{Does secondary seed dispersal of $C$. coenobialis occur along the longitudinal course of a stream, thus leading to accumulation of genetic diversity in downstream local populations?}

Studies have shown that gene flow between populations is largely congruent with river basins and the direction 
of water flow within and among them, suggesting that rivers and streams are important for seed dispersal [89, 90]. Indeed, river and stream habitats have long been recognized as corridors for riparian plants [35, 38, 91]. The 'unidirectional dispersal hypothesis' [36] predicts that downstream accumulation of genetic diversity results from the movement of seeds and propagules from upstream to downstream populations due to a continuous influx of alleles. Some studies have demonstrated such a relationship between the position of plant populations along the longitudinal course of a river and the degree of genetic diversity within these populations [32, $33,35,92]$. In contrast, the present study based on both cPDNA and ISSR data showed that the genetic diversity in local populations of $C$. coenobialis at downstream locations was significantly lower than upstream, whether in the linear streamside local populations across DH $(H$ : 0.091 vs 0.136 ) or in the dendritic streamside local populations across NK ( $H: 0.079$ vs $0.112,0.110)$. This implies that downstream local populations do not accumulate genetic diversity, which we attribute to the absence of movement of seeds and propagules from upstream to downstream local populations. This was confirmed by a lack of accumulation of particular cpDNA haplotypes in downstream local populations (e.g. DH: local population-FST; NK: local population-SH), whether in the linear streamside local populations across DH (haplotypes $\mathrm{H} 7, \mathrm{H} 8)$ or in the dendritic streamside local populations across NK (h6, h7, h11, h12). In addition, the high degree of differentiation and low level of gene flow $(\mathrm{Nm})$ among local populations of $C$. coenobialis also suggests that seed dispersal among streamside local populations has been restricted across both DH and NK. The limited seed dispersal in C. coenobialis is apparent from the significant positive autocorrelation of spatial genetic structure being detected only at $0.20-0.92 \mathrm{~m}$. Our field observations showed that the small seeds of $C$. coenobialis, which adhere to the axial placentation in an unilocular capsule that opens via a large oval slit in the upper part (Fig. S1), can be dispersed by rain splash [66, 67], like other species of the same genus $[93,94]$. However, the stream terrain in mountainous areas is complex, characterized by irregular topography and geographical obstacles, which prevent the minute $C$. coenobialis seeds being propagated over long distances by water along the stream. This therefore reduces gene flow and increases genetic divergence among plant populations. Moreover, the plant hangs on rock walls near streams in monsoon forests, which means that upstream seeds are less likely to deposit among downstream local populations. We suggest that, recently at least, stream basins and the direction of water flow are not important for seed dispersal of $C$. coenobialis among local populations; in other words, such streams are not acting as corridors for propagation. However, the ancestral haplotypes shared among local populations across both $\mathrm{DH}(\mathrm{H} 1, \mathrm{H} 2$, and $\mathrm{H} 6)$ and $\mathrm{NK}(\mathrm{h} 1, \mathrm{~h} 3$, and $\mathrm{h} 5)$ indicate that the connectivity of selfing C. coenobialis local populations in the two mountain areas studied could be attributed to historical gene flows, which occurred between the Holocene and Pleistocene. Further study is needed to investigate these hypotheses in more detail.

\section{Materials and methods}

\section{Species, study sites and sampling design}

Caulokaempferia coenobialis (Hance) K. Larsen (Fig. S1) is a deciduous perennial nonclonal herb of up to $50 \mathrm{~cm}$ in height that is endemic in the Guangdong, Guangxi, and Yunnan provinces of south China, where it grows on rock walls usually along streams in humid monsoon forests and is over the streams ca. 1-4 m. The plant flowers in May to August and is self-fertilizing by virtue of pollen sliding to the stigma through an oily emulsion [64-66]. Capsules mature within 22 days, and burst open or dehisce [64-66]. Seeds are small (ca. $1.65 \pm 0.06 \mathrm{~mm}$ $\times 0.59 \pm 0.07 \mathrm{~mm}$ ) and ellipsoid-ovoid, without aril and appendages to aid wind dispersal, and dispersed by rain splash, and then germinate and develop into seedlings that develop rhizomes before the plants die back between September and November $[64,66,67]$.

To investigated the patterns of genetic diversity and structure within and between populations in subtropical monsoon forest at a fine scale, two metapopulations with different streamside local population systems were studied in the Dinghu Mountain National Nature Reserve (DH: $\quad 23^{\circ} 09^{\prime} 21^{\prime \prime}-23^{\circ} 11^{\prime} 30^{\prime \prime} \quad \mathrm{N}, \quad 112^{\circ} 30^{\prime} 39^{\prime \prime}-112^{\circ} 33^{\prime} 41^{\prime \prime}$ E, alt. $1000.3 \mathrm{~m})$ and Nankun Mountain Provincial Nature Reserve (NK: $23^{\circ} 35^{\prime} 14^{\prime \prime}-23^{\circ} 43^{\prime} 05^{\prime \prime} \mathrm{N}, 113^{\circ} 48^{\prime} 41^{\prime \prime}$ $113^{\circ} 56^{\prime} 32^{\prime \prime} \mathrm{E}$, alt. $1210 \mathrm{~m}$ ), both in Guangdong, but separated by nearly $160 \mathrm{~km}$ (Table 1, Fig. 2A). The DH metapopulation consists of four streamside local populations along a linear perennial stream (pop. JLS, TXL, RZPB, and FST, Fig. 2 B1), which are naturally separated by $300 \mathrm{~m}-2.3 \mathrm{~km}$ (average ca. $583 \mathrm{~m}$ ), with little interference from human activities. The NK metapopulation consists of nine local populations, which are split into two subsets, the West-North area (NK-I) and the East-South area (NK-II), by the G355 National Road along a valley in Nankun Mountain (Fig. 2 B2), and are greatly disturbed by human activities. The subset in the West-North area consists of five streamside local populations along a dendritic perennial stream (pop. TTD, TYSZ, GYT, XXPB, and $\mathrm{SH}$ ), which are separated by $1.2 \mathrm{~km}-5.9 \mathrm{~km}$ (average ca. $2.1 \mathrm{~km}$ ) of farmland, village, road and mountain forest. The subset in the East-South area consist of four streamside (pop. YXT, YTH and SLCX) or forested (pop. SLCL) local populations in a complex transverse 
hydrological system, which are isolated by average $333 \mathrm{~m}-2.2 \mathrm{~km}$ (average ca. $541 \mathrm{~m}$ ) of mountain forest, agricultural land, village, road and holiday villa. In each local population, we sampled 20 adult individuals (except pop. FST: 10 individuals at least $0.5 \mathrm{~m}$ apart) throughout the area of distribution of each local population; there are ca. 500 to 10,000 mature individuals per local population (Table 1). The straight-line distance between individuals was also estimated directly on the basis of the site coordinates to test the spatial autocorrelation coefficient (r) within local populations. Leaf tissue samples were stored in silica gel for DNA analysis. The formal identification of plant materials was performed by the correspondence author, Professor Ying-Qiang Wang. The herbarium vouchers of C. coenobialis (WYQ-HHDBJ-5 and LGHHHDBJ-81) were deposited in the Herbarium of School of Life Science, South China Normal University (SN). The field work permits were obtained from the Dinghu Mountain National Nature Reserve Administration and the Nankun Mountain Provincial Nature Reserve Administration. The sample collection work and molecular experiments complied with local legislation, national and international guidelines, and did not involve protected species. We also abide by the Convention on the Trade in Endangered Species of Wild Fauna and Flora.

\section{DNA extraction, chloroplast DNA sequencing and ISSR fragment analysis}

Total genomic DNA was extracted from 0.2 to $0.5 \mathrm{~g}$ dried leaves using a modified 2\% CTAB protocol [95]. The quality and concentration of the extracted DNA were estimated on a $0.8 \%$ agarose gel and a Nano-100 spectrophotometer (Allsheng, China).

We screened eight non-coding plastid DNA regions that have revealed substantial levels of polymorphism based on chloroplast genome sequence of Zingiber spectabile [96] and then selected the two most variable cpDNA regions for analysis, including one intergenic spacer region (psbJ-petA) and one gene intron (trnL intron). Reactions were performed in a total volume of $20 \mu \mathrm{L}$ containing $2.0 \mu \mathrm{L} 10 \times$ PCR buffer, $1.5 \mathrm{mM} \mathrm{MgCl}_{2}$, $0.2 \mathrm{mM}$ dNTPs, $0.25 \mu \mathrm{M}$ forward primer, $0.25 \mu \mathrm{M}$ reverse primer, 0.75 units Taq polymerase, $37.5 \mathrm{ng}$ template DNA and double-distilled water. Polymerase chain reactions (PCRs) were conducted on a Bio-Rad $\mathrm{T} 100^{\mathrm{TM}}$ Thermal Cycle (Bio-Rad, Singapore) under the following conditions: initial denaturation at $94{ }^{\circ} \mathrm{C}$ for $5 \mathrm{~min}$, followed by 39 cycles of $45 \mathrm{~s}$ at $94{ }^{\circ} \mathrm{C}, 45 \mathrm{~s}$ at a primer-specific annealing temperature, extension for $90 \mathrm{~s}$ at $72{ }^{\circ} \mathrm{C}$, and a 10-min final extension step at $72{ }^{\circ} \mathrm{C}$. The PCR products were sequenced with an $\mathrm{ABI}$ 3730XL automated sequencer (Applied Biosystems, Foster City, CA).
For ISSR analysis, ten polymorphic primers (807, $808,810,835,836,840,841,847,859$, and 887) were selected from 100 ISSR primers obtained from the University of British Columbia. Reactions were performed in a total volume of $20 \mu \mathrm{L}$ containing $2.0 \mu \mathrm{L} 10 \times$ PCR buffer, $1.5 \mathrm{mM} \mathrm{MgCl}_{2}, 0.2 \mathrm{mM}$ dNTPs, $1.0 \mu \mathrm{M}$ primer, 1.5 units Taq polymerase, $50 \mathrm{ng}$ template DNA and double-distilled water. ISSR PCR conditions were consistent with cpDNA PCR conditions. Amplification products were electrophoretically separated in $1.8 \%$ agarose gels, together with a $100 \mathrm{bp}$ ladder as a size marker, and visualized on a UV transilluminator (Bio-Rad Gel Doc XR+, America). All clear and reproducible amplified fragments were scored as presence (1) or absence (0) and converted into a binary data matrix. The annealing temperatures for cPDNA and ISSR primers are given in Table 2.

\section{Data analysis}

\section{Genetic diversity, genetic differentiation and gene flow}

For the cpDNA dataset, sequence data were aligned using MEGA X [97] and were manually adjusted where necessary. Contiguous indels were treated as single mutation events and coded as substitutions (A or T) [98]. The number of haplotypes, haplotype diversity $(h)$, nucleotide diversity $(\pi)$ and gene flow $(\mathrm{Nm})$ were calculated using DNASP v5.1 [99]. The permutation test implemented in PERMUT was employed to compare parameters of local population differentiation with ordered alleles $\left(F_{\mathrm{ST}}\right)$ based on 1000 random permutations [100]. Pairwise estimates of uncorrected sequence divergence (Dxy, Kimura 2-parameter model) among local populations were calculated in MEGA X. Standard deviations were determined using 1000 bootstrap replicates.

For the ISSR dataset, Nei's gene diversity $(H)$ [101], Shannon's index $(I)$ [102], percentage of polymorphic loci (PPL), gene differentiation $\left(G_{\mathrm{ST}}\right)$ [103], and gene flow were estimated using the program POPGENE version 1.32 [104], assuming complete selfing within local populations $(F \mathrm{is}=1)$ because $C$. coenobialis plants are selffertilization $[64,65]$. Pairwise estimates of Nei's genetic distance among local populations were calculated in POPGENE version 1.32.

In order to quantify the variation in cpDNA sequences and ISSR gene frequency among local populations, we performed analyses of molecular variance (AMOVA) in ARLEQUIN v3.1 [105] and GENALEX ver.6.5 [106] using $R$ - and $\Phi$-statistics, respectively. The significance of fixation indices was tested using 1,000 and 999 permutations, respectively [107]. 


\section{Genetic structure and cluster analysis}

For the cpDNA dataset, phylogenetic trees were constructed to reveal the relationships among haplotypes. Relationships for the identified haplotypes were reconstructed using maximum likelihood (ML) and Bayesian inference (BI). Two individuals of Pyrgophyllum yunnanense and Kaempferia rotunda were used as the outgroup. ML analysis was carried out using MEGA $X$ and the appropriate model $(\mathrm{T} 92+\mathrm{G}+\mathrm{I})$ of DNA substitution was determined using the Akaike information criterion (AIC) as the selection criterion. The ModelFinder in PhyloSuite v.1.1.15 [108] was applied to find the F81 + F+I model for BI methods based on the AIC. BI analysis was conducted in MrBayes 3.2.6 [109] with the following settings: 1,000,000 metropolis-coupled Markov chain Monte Carlo (MCMC) generations, sample frequency of 1,000 and burn-in parameter set at 2,500. Then, as no fossil records are available to calibrate the intergenic spacer substitution rate for genus Caulokaempferia, branch lengths of the clock-constrained ML tree were transformed into absolute time by assuming the substitution rates of these spacers to be $1.2-1.7 \times 10^{-9}$ substitutions per site per year $(\mathrm{s} / \mathrm{s} / \mathrm{y})$ in MEGA X. This is a rough estimate of the substitution rate in non-coding chloroplast regions of seed plants, which can be used to estimate the divergence time of taxa without fossil records in the same study area (e.g., Sinopodophyllum hexandrum, [110]; Rosa soulieana, [111]).

For the ISSR datasets, a Bayesian cluster was implemented using STRUCTURE version 2.2 [112]. Five independent runs were performed for each $K$, from $K=1$ to 4 for the DH metapopulation and from $K=1$ to 9 for the NK metapopulation. All runs were performed with the admixture model, with burn-in and run lengths of 100,000 and 1,000,000 iterations, respectively. The optimal number of clusters $(\Delta \mathrm{K})$ was determined following the guidelines of [112] and the recommendations of Evanno et al. [113]. Individual assignment coefficients (q) for each genetic cluster were then averaged using Clumpp software [114] to correct for any discrepancies between runs. To further test the genetic relationship among individuals, we constructed a neighbor-joining (NJ) tree based on Nei's genetic distance using the program DARwin 6.0.9 [115] with 1,000 re-samples for bootstrap support, an unweighted pair-group method arithmetic mean (UPGMA) dendrogram based on Nei's similarity coefficient using NTSYS 2.1 [116], and principal coordinate analysis (PCoA) based on Nei's genetic distance in GenAlEx ver. 6.5.

\section{Analysis of spatial genetic structure}

To test the relationship of geographical distance and genetic structure between local populations on a microgeographic scale, a Mantel test was performed in GENALEX ver.6.5 for ISSR data and ARLEQUIN v3.1 for cpDNA data, respectively. To detect spatial genetic structure (SGS) within a local population, the genetic relatedness of individuals relative to their spatial position within the TXL local population in DH was analyzed by spatial autocorrelation analyses in GenAlEx. The even sample classes were chosen because this was particularly useful for reducing noisy confidence limits when sample sizes were very uneven. Two-tailed probability values were calculated and bootstrap resampling was performed 999 times.

\section{Conclusion}

Using polymorphic ISSR and cpDNA loci, we studied the effect at a microgeographic scale of different stream systems (a linear stream, a dendritic stream, and complex transverse hydrological system) in subtropical monsoon forest on the genetic structure and connectivity of a riparian self-fertilizing herb Caulokaempferia coenobialis populations, which does not use anemochory or zoochory for seed dispersal, across Dinghu Mountain and Nankun Mountain. Such studies could contribute to an improved understanding of the effect of rivers or streams on population genetic diversity and structure in riparian plants. Our results show that streams are not acting as corridors for dispersal of $C$. coenobialis and the connectivity of local populations can be attributed to historical gene flows, resulting in a lack of spatial genetic structure, despite self-fertilization. Selfing $C$. coenobialis can maintain high genetic diversity through genetic differentiation, which is intensified by local adaptation and neutral mutation and/or genetic drift in local populations at a microgeographic scale.

\section{Supplementary Information}

The online version contains supplementary material available at https://doi. org/10.1186/s12870-021-03101-7.

Additional file 1:Fig. S1.Caulokaempferia coenobialis. a: plant, flower and habitat; b: seeds adhered to the axial placentation in an unilocular capsule opening by a large oval slit; c: seeds dispersed by rain splash. Fig. S2. Line graph of genetic cluster (K) vs. Delta K for metapopulations DH (A) and NK (B). Fig. S3. UPGMA dendrogram based on Nei's genetic identity for individuals of Caulokaempferia coenobialis in metapopulations DH (A) and NK (B). Table S1. Inter Simple Sequence Repeat (ISSR) data for Caulokaempferia coenobialis.

\section{Acknowledgements}

We are indebted to the Dinghu Mountain National Nature Reserve Administration and the Nankun Mountain Provincial Nature Reserve Administration for allowing us to collect the plant samples. We are grateful for the two anonymous reviewers' excellent suggestions to improve the manuscript. 


\section{Authors' contributions}

Y.-Q. Wang designed the study, collected field samples, analysed all data and wrote the manuscript; Q. Fu participated in part of the cPDNA and ISSR molecular experiments, analysed all data and wrote the manuscript; J. Deng conducted the cpDNA molecular experiments, M. Chen conducted the ISSR molecular experiments, Y. Zhong conducted the Fig. 7 and related molecular experiments and G.-H. Lu investigated and collected field samples. All authors read and approved the final manuscript.

\section{Funding}

This work was funded by the Joint Fund of National Natural Science Foundation of China and Guangdong Provincial Government (No. U1301213) and the National Natural Science Foundation of China (30570116) and the key project of the Natural Science Foundation of Guangdong Province of China (7117864). These funding bodies had no role in the design of the study and collection, analysis, and interpretation of data and in writing the manuscript.

\section{Availability of data and materials}

The two plastomic data analyzed in this study are deposited into the NCBI database (https://www.ncbi.nlm.nih.gov/nucleotide/) with accession numbers: MW849477-MW849520; Inter Simple Sequence Repeat (ISSR) data for Caulokaempferia coenobialis is available as Supplementary Information.

\section{Declarations}

\section{Ethics approval and consent to participate}

Not applicable.

\section{Consent for publication}

Not applicable.

\section{Competing interests}

The authors declare that they have no competing interests.

\section{Author details}

${ }^{1}$ Guangdong Provincial Key Laboratory of Biotechnology for Plant Development, School of Life Sciences, South China Normal University, Guangzhou, China. ${ }^{2}$ Guangzhou Key Laboratory of Subtropical Biodiversity and Biomonitoring, School of Life Sciences, South China Normal University, Guangzhou, China.

Received: 27 January 2021 Accepted: 16 June 2021

Published online: 08 July 2021

\section{References}

1. Dawson K, Simons AJ, Waugh R, Powell W. Diversity and genetic differentiation among subpopulations of Gllricidia sepium revealed by PCR-based assays. Heredity. 1995;74:10-8.

2. Han YC, Teng CZ, Wahiti GR, Zhou MQ, Hu ZL, Song YC. Mating system and genetic diversity in natural populations of Nelumbo nucifera (Nelumbonaceae) detected by ISSR markers. Plant Syst Evol. 2009;277:13-20.

3. Schaal BA, Hayworth DA, Olsen KM, Rauscher JT, Smith WA. Phylogeographic studies in plants: problems and prospects. Mol Ecol. 1998;7:465-74.

4. Govindaraj M, Vetriventhan M, Srinivasan M. Importance of genetic diversity assessment in crop plants and its recent advances: an overview of its analytical perspectives. Genet Res Int. 2015. https://doi.org/ $10.1155 / 2015 / 431487$.

5. Yan J, Zhu MD, Liu W, Xu Q, Zhu CY, Li JQ, Sang T. Genetic variation and bidirectional gene flow in the riparian plant Miscanthus lutarioriparius, across its endemic range: implications for adaptive potential. GCB Bioenergy. 2016:8:764-76.

6. Baker WL. The landscape ecology of large disturbances in the design and management of nature reserves. Landscape Ecol. 1992;7:181-94.

7. Barnosky AD, Hadley EA, Bascompte J, Berlow EL, Brown JH, Fortelius M, et al. Approaching a state shift in Earth's biosphere. Nature. 2012:486:52-8.
8. Carvallo GO, Vergara-Meriño B, Díaz A, Villagra CA, Guerrero PC. Rocky outcrops conserve genetic diversity and promote regeneration of a threatened relict tree in a critically endangered ecosystem. Biodivers Conserv. 2019;28:2805-24.

9. Picó FX, Van Groenendael J. Large-scale plant conservation in European semi-natural grass-lands: a population genetic perspective. Divers Distrib. 2007:13:920-6.

10. Mijangos JL, Pacioni C, Spencer PBS, Craig MD. Contribution of genetics to ecological restoration. Mol Ecol. 2015;24:22-37.

11. Lindenmayera DB, Franklinb JF, Fischera J. General management principles and a checklist of strategies to guide forest biodiversity conservation. Biol Conserv. 2006;131:433-45.

12. Hardesty BD, Dick CW, Kremer A, Hubbell S, Bermingham E. Spatial genetic structure of Simarouba amara Aubl. (Simaroubaceae), a dioecious, animal-dispersed Neotropical tree, on Barro Colorado Island, Panama. Heredity. 2005:95:290-7.

13. Zeng X, Michalski SG, Fischer M, Durka W. Species diversity and population density affect genetic structure and gene dispersal in a subtropical understory shrub. J Plant Ecol. 2012;5:270-8.

14. He J, Li XY, Gao DD, Zhu P, Wang ZF, Wang ZM, Ye WH, Cao HL. Topographic effects on fine-scale spatial genetic structure in Castanopsis chinensis Hance (Fagaceae). Plant Spec Biol. 2013;28:87-93.

15. Duminil J, Daïnou K, Kaviriri DK, Gillet P, Loo J, Doucet JL, Hardy OJ. Relationships between population density, fine-scale genetic structure, mating system and pollen dispersal in a timber tree from African rainforests. Heredity. 2016;116:295-303.

16. Ewédjè EBK, Ahanchédé A, Hardy OJ. Breeding system, gene dispersal and small-scale spatial genetic structure of a threatened food tree species, Pentadesma butyracea (Clusiaceae) in Benin. Conserv Genet. 2017;18:799-811.

17. Sander NL, Pérez-Zavala F, Da Silva CJ, Arruda JC, Pulido MT, Barelli MAA, et al. Rivers shape population genetic structure in Mauritia flexuosa (Arecaceae). Ecol Evol. 2018;8:6589-98.

18. Murray BF, Reid MA, Capon SJ, Thoms M, Wu SB. Gene flow and genetic structure in Acacia stenophylla (Fabaceae): Effects of hydrological connectivity. J Biogeogr. 2019;46:1138-51.

19. Nagamitsu T, Shuri K, Kikuchi S, Koike S, Naoe S, Masaki T. Multiscale spatial genetic structure within and between populations of wild cherry trees in nuclear genotypes and chloroplast haplotypes. Ecol Evol. 2019:9:11266-76.

20. Ony MA, Nowicki M, Boggess SL, Klingeman WE, Zobel JM, Trigiano RN, Hadziabdic D. Habitat fragmentation influences genetic diversity and differentiation: Fine-scale population structure of Cercis canadensis (eastern redbud). Ecol Evol. 2020;10:3655-70.

21. Machon N, Bardin P, Mazer SJ, Moret J, Godelle B, Austerlitz F. Relationship between genetic structure and seed and pollen dispersal in the endangered orchid Spiranthes spiralis New Phytol. 2003;157:677-87.

22. Kitamoto N, Honjo M, Ueno S, Takenaka A, Tsumura Y, Washitani I, Ohsawa R. Spatial genetic structure among and within populations of Primula sieboldii growing beside separate streams. Mol Ecol. 2005:14:149-57.

23. Huang Y, Zhang CQ, Li DZ. Low genetic diversity and high genetic differentiation in the critically endangered Omphalogramma souliei (Primulaceae): implications for its conservation. J Syst Evol. 2009;47:103-9.

24. Brzosko E, Ostrowiecka B, Kotowicz J, Bolesta M, Gromotowicz A, Gromotowicz M, et al. Seed dispersal in six species of terrestrial orchids in Biebrza National Park (NE Poland). Acta Soc Bot Pol. 2017;86:3557.

25. Chung MY, Nason JD, López-Pujol J, Chung JM, Kim KJ, Maki M, Chung MG. Fine-scale genetic structure in populations of the spring ephemeral herb Megaleranthis saniculifolia (Ranunculaceae). Flora. 2018;240:16-24.

26. Fu Q, Lu GH, Fu YH, Wang YQ. Genetic differentiation between two varieties of Oreocharis benthamii (Gesneriaceae) in sympatric and allopatric regions. Ecol Evol. 2020;10:7792-805.

27. Schleuning M, Becker T, Vadillo GP, Hahn T, Matthies D, Durka W. River dynamics shape clonal diversity and genetic structure of an Amazonian understorey herb. J Eco. 2011;99:373-82.

28. Chen YY, Chu HJ, Liu H, Liu YL. Abundant genetic diversity of the wild rice Zizania latifolia in central China revealed by microsatellites. Ann Appl Biol. 2012;161:192-201. 
29. Jansson R, Zinko U, Merritt DM, Nilsson C. Hydrochory increases riparian plant species richness: a comparison between a free-flowing and a regulated river. J Ecol. 2005;93:1094-103.

30. Nilsson C, Brown RL, Jansson R, Merritt DM. The role of hydrochory in structuring riparian and wetland vegetation. Biol Rev. 2010;85:837-58,

31. Akimoto M, Shimamoto Y, Morishima H. Population genetic structure of wild-rice Oryza glumaepatula distributed in the Amazon flood area influenced by its life history traits. Mol Ecol. 1998;7:1371-81.

32. Lundqvist $E$, Andersson $E$. Genetic diversity in populations of plants with different breeding and dispersal strategies in a free-flowing boreal river system. Hereditas. 2001;135:75-83.

33. Imbert E, Lefèvre F. Dispersal and gene flow of Populus nigra along a dynamic river system. J Ecol. 2003:91:447-56.

34. Kudoh H, Shimamura R, Takayama K, Whigham DF. Consequences of hydrochory in Hibiscus. Plant Spec Biol. 2006;21:127-33.

35. Fér T, Hroudová Z. Detecting dispersal of Nuphar lutea in river corridors using microsatellite markers. Freshwater Biol. 2008;53:1409-22.

36. Ritland K. Genetic differentiation, diversity, and inbreeding in the mountain monkeyflower (Mimulus caespitosus) of the Washington Cascades. Can J Bot. 1989:67:2017-24.

37. Russell JR, Weber JC, Booth A, Powell W, Sotelo-Montes C, Dawson IK. Genetic variation of Calycophyllum spruceanum in the Peruvian Amazon Basin, revealed by amplified fragment length polymorphism (AFLP) analysis. Mol Ecol. 1999;8:199-204.

38. Tero N, Aspi J, Siikamäki P, Jäkäläniemi A, Tuomi J. Genetic structure and gene flow in a metapopulation of an endangered plant species Silene tatarica Mol Ecol. 2003;12:2073-85.

39. Markwith SH, Scanlon MJ. Multiscale analysis of Hymenocallis coronaria (Amaryllidaceae) genetic diversity, genetic structure, and gene movement under the influence of unidirectional stream flow. Am J Bot. 2007:94:151-60

40. Wei XZ, Meng HJ, Bao DC, Jiang MX. Gene flow and genetic structure of a mountain riparian tree species, Euptelea pleiospermum (Eupteleaceae): how important is the stream dendritic network? Tree Genet Genomes. 2015:11:64.

41. Chen Y, Liu Y, Fan X, Li W, Liu Y. Landscape-scale genetic structure of wild rice Zizania latifolia: the roles of rivers mountains and fragmentation. Front Ecol Evol. 2017;5:17.

42. Tsuda Y, Sawada H, Ohsawa T, Nakao K, Nishikawa H, Ide Y. Landscape genetic structure of Betula maximowicziana in the Chichibu mountain range, central Japan. Tree Genet Genomes. 2010;6:377-87.

43. Werth S, Schodl M, Scheidegger C. Dams and canyons disrupt gene flow among populations of a threatened riparian plant. Freshwater Biol. 2014;59:2502-15.

44. Williams CF, Ruvinsky J, Scott PE, Hews DK. Pollination, breeding system, and genetic structure in two sympatric Delphinium (Ranunculaceae) species. Am J Bot. 2001;88:1623-33.

45. Aizen MA, Ashworth L, Galetto L. Reproductive success in fragmented habitats: do compatibility systems and pollination specialization matter? J Veg Sci. 2002;13:885-92.

46. Charlesworth D. Effects of inbreeding on the genetic diversity of populations. Philos T R Soc B: Biol Sci. 2003;358:1051-70.

47. Ennos RA. Estimating the relatve rates of pollen and seed migration among plant populations. Heredity. 1994;72:250-9.

48. Latta RG, Linhart YB, Fleck D, Elliit M. Direct and indirect estimates of seed versus pollen movement within a population of ponderosa pine. Evolution. 1998:52:61-7.

49. Oddou-Muratorio S, Klein EK, Austerlitz F. Pollen flow in the wildservice tree, Sorbus torminalis (L.) Crantz. II. Pollen dispersal and heterogeneity in mating success inferred from parent-offspring analysis. Mol Ecol. 2005;14:4441-52.

50. Jacquemyn H, Vandepitte K, Brys R, Honnay O, Roldán-Ruiz I. Fitness variation and genetic diversity in small, remnant populations of the food deceptive orchid Orchis purpurea Biol Conserv. 2007;139:203-10.

51. Ohhayashi K, Hodoki Y, Kondo NI, Kunii H, Shimada M. A massive tsunami promoted gene flow and increased genetic diversity in a near threatened plant species. Sci Rep-UK. 2017;7:10933.

52. Hamrick JL, Godt MJW. Effects of life history traits on genetic diversity in plant species. Philos T R Soc B: Biol Sci. 1996;351:1291-8.

53. Nybom $\mathrm{H}$. Comparison of different nuclear DNA markers for estimating intraspecific genetic diversity in plants. Mol Ecol. 2004;13:1143-55.
54. Reisch C, Bernhardt-Römermann M. The impact of study design and life history traits on genetic variation of plants determined with AFLPS. Plant Ecol. 2014;215:1493-511.

55. Huang R, Chu QH, Lu GH, Wang YQ. Comparative studies on population genetic structure of two closely related selfing and outcrossing Zingiber species in Hainan Island. Sci Rep-UK. 2019;9:17997.

56. Huang $R$, Zhang ZD, Wang $Y$, Wang $Y Q$. Genetic variation and genetic structure within metapopulations of two closely related selfing and outcrossing Zingiber species (Zingiberaceae). AoB PLANTS. 2021;13:1-15.

57. Shimamura R, Kachi N, Kudoh H, Whigham DF. Hydrochory as a determinant of genetic distribution of seeds within Hibiscus moscheutos (Malvaceae) populations. Am J Bot. 2007:94:1137-45.

58. Hart KH, Cox PA. Dispersal ecology of Nuphar luteum (L.) Sibthorp \& Smith: abiotic seed dispersal mechanisms. Biol J Linn Soc. 1995;119:87-100

59. Peakall R, Beattie AJ. Does ant dispersal of seeds in Sclerolaena diacantha (Chenopodiaceae) generate local spatial genetic structure? Heredity. 1995;75:351-61.

60. Alvarez-Buylla ER, Chaos A, Piñero D, Garay AA. Demographic genetics of a pioneer tropical tree species: patch dynamics, seed dispersal, and seed banks. Evolution. 1996:50:1155-66.

61. Kalisz S, Hanzawa FM, Tonsor SJ, Thiede A, Voigt S. Ant-mediated dispersal alters patterns of relatedness in a population of Trillium grandiflorum. Ecology. 1999;80:2620-34.

62. Kudoh $\mathrm{H}$, Whigham DF. Microgeographic genetic structure and gene flow in Hibiscus moscheutos (Malvaceae) populations. Am J Bot. 1997;84:1285-93.

63. Wu TL, Chen SZ. Flora of China, vol. 16. Beijing: Science Press; 1981.

64. Wang YQ, Zhang DX, Renner SS, Chen ZY. A new self-pollination mechanism. Nature. 2004:431:39-40.

65. Wang YQ, Zhang DX, Renner SS, Chen ZY. Self-pollination by sliding pollen in Caulokaempferia coenobialis (Zingiberaceae). Int J Plant Sci. 2005;166:753-9.

66. Wang YQ. Studies on pollination biology in Zingiberaceae. Doctoral dissertation. Guangzhou: South China Botanical Garden, Chinese Academy of Science; 2005

67. Lu GH. Study on reproductive ecology of Caulokaempferia coenobialis. Master Dissertation. Guangzhou: South China Normal University; 2008.

68. Sweigart AL, Willis JH. Patterns of nucleotide diversity in two species of Mimulus are affected by mating system and asymmetric introgression. Evolution. 2003;57:2490-506

69. Glémin S, Bazin E, Charlesworth D. Impact of mating systems on patterns of sequence polymorphism in flowering plants. P Roy Soc B: Biol Sci. 2006;273:3011-9.

70. St Onge KR, Källman T, Slotte T, Lascoux M, Palmé AE. Contrasting demographic history and population structure in Capsella rubella and Capsella grandiflora, two closely related species with different mating systems. Mol Ecol. 2011;20:3306-20.

71. Whitlock MC, Barton NH. The effective size of a subdivided population. Genetics. 1997:146:427-41.

72. Pannell JR, Charlesworth B. Effects of metapopulation processes on measures of genetic diversity. Philos T R Soc B: Biol Sci. 2000;355:1851-64.

73. Slatkin M. Gene flow and the geographic structure of natural populations. Science. 1987;236:787-92.

74. Hutchison DW, Templeton AL. Correlation of pairwise genetic and geographic distance measures: inferring the relative influences of gene flow and drift on the distribution of genetic variability. Evolution. 1999;53:1898-914.

75. Real LA. Ecological genetics. Princeton: Princeton University Press; 1994.

76. Nevo ER, Noy R, Lavie B, Beiles A, Muchtar S. Genetic diversity and resistance to marine pollution. Bot J Linn Soc. 1986;29:139-44.

77. Vekemans $X$, Hardy OJ. New insights from fine-scale spatial genetic structure analyses in plant populations. Mol Ecol. 2004;13:921-35.

78. Duminil J, Hardy OJ, Petit RJ. Plant traits correlated with generation time directly affect inbreeding depression and mating system and indirectly genetic structure. BMC Evol Biol. 2009;9:177-90.

79. Bartkowska MP, Wong AYC, Sagar SP, Zeng L, Eckert CG. Lack of spatial structure for phenotypic and genetic variation despite high 
self-fertilization in Aquilegia canadensis (Ranunculaceae). Heredity 2018;121:605-15.

80. Mitsui Y, Isagi Y, Setoguchi H. Multiple spatial scale patterns of genetic diversity in riparian populatioins of Ainsliaea faurieana (Asteraceae) on Yakushima Island. Japan Am J Bot. 2010;97:101-10.

81. Young A, Boyle T, Brown T. The population genetic consequences of habitat fragmentation for plants. Trends Ecol Evol. 1996;11:413-8.

82. Rocha OJ, Aguilar G. Reproductive biology of the dry forest tree Enterolobium cyclocarpum (Guanacaste) in Costa Rica: a comparison between trees left in pastures and trees in continuous forest. Am J Bot. 2001;88:1607-14.

83. Ghazoul J. Pollen and seed dispersal among dispersed plants. Biol Rev. 2005:80:413-43.

84. Kettle CJ, Hollingsworth PM, Jaffré T, Moran B, Ennos RA. Identifying the early genetic consequences of habitat degradation in a highly threatened tropical conifer Araucaria nemorosa Laubenfels. Mol Ecol. 2007;16:3581-91.

85. Finger A, Kettle CJ, Kaiser-Bunbury CN, Valentin T, Doudee D, Matatiken D, Ghazoul J. Back from the brink: potential for genetic rescue in a critically endangered tree. Mol Ecol. 2011;20:3773-84.

86. Toczydlowski RH, Waller DM. Drift happens: molecular genetic diversity and differentiation among populations of jewelweed (Impatiens capensis Meerb.) reflect fragmentation of floodplain forests. Mol Ecol. 2019;28:2459-75.

87. Bureau of Geology and Mineral Resources of Guangdong Province. Reginal geology of Guangdong Province. Beijing: Geological Publishing House; 1988. In Chinese.

88. LiWR. Nankun mountain national protecting bio-hydrogeology characteristics. J Eng Geol. 2007;15:465-70 [in Chinese].

89. Kudoh $\mathrm{H}$, Whigham DF. A genetic analysis of hydrologically dispersed seeds of Hibiscus moscheutos (Malvaceae). Am J Bot. 2001:88:588-93.

90. Liu YF, Wang Y, Huang HW. High inter-population genetic differentiation and unidirectional linear migration patterns in Myricaria laxiflora (Tamaricaceae), an endemic riparian plant in the Three Gorges Valley of the Yangtze River. Am J Bot. 2006;93:206-15.

91. Wei XZ, Meng HJ, Jiang MX. Landscape genetic structure of a streamside tree species Euptelea pleiospermum (Eupteleaceae): contrasting roles of river valley and mountain ridge. PLoS ONE. 2013;8:e66928.

92. Gornall RJ, Hollingsworth PM, Preston CD. Evidence for spatial structure and directional gene flow in a population of an aquatic plant Potamogeton coloratus Heredity. 1998;80:414-21.

93. Larsen K, Khaw SH, Saw LG. Gingers of Peninsular Malaysia and Singapore. Borneo: Natural History Publication; 1999.

94. Larsen K, Saksuwan LS. Gingers of Thailand. Thailand: Queen Sirikit Botanic Garden and The Botanical Garden Organization; 2006.

95. Doyle JJ, Doyle JL. A rapid DNA isolation procedure for small quantities of fresh leaf tissue. Phytochem Bull. 1978;19:11-5.

96. Barretta CF, Davisa JI, Leebens-Mackb J, Conranc JG, Stevensond DW. Plastid genomes and deep relationships among the commelinid monocot angiosperms. Cladistics. 2013;29:65-87.

97. Kumar S, Stecher G, Li M, Knyaz C, Tamura K. MEGA X: Molecular evolutionary genetics analysis across computing platforms. Mol Biol Evol. 2018:35:1547-9.

98. Simmons MP, Ochoterena H. Gaps as characters in sequence-based phylogenetic analyses. Syst Biol. 2000:49:369-81.

99. Librado P, Rozas J. DnaSP v5: a software for comprehensive analysis of DNA polymorphism data. Bioinformatics. 2009;25:1451-2.
100. Pons O, Petit RJ. Measuring and testing genetic differentiation with ordered versus unordered alleles. Genetics. 1996;144:1237-45.

101. Nei M. Genetic distance between populations. Am Nat. 1972;106:283-92.

102. Shannon CE, Weaver W. The mathematical theory of communication. Urbana: University of Illinois Press; 1949.

103. Nei M. Molecular evolution genetics. New York: Columbia University Press; 1987.

104. Yeh FC, Yang RC, Boyle TBJ, Ye ZH, Mao JX. POPGENE, the user-friendly shareware for population genetic analysis. Alberta: Molecular Biology and Biotechnology Centre, University of Alberta; 1997.

105. Excoffier L, Laval G, Schneider S. Arlequin ver. 3.1: an integrated software package for population genetics data analysis. Bern: Computational and Molecular Population Genetics Laboratory, Institute of Zoology, University of Bern; 2006.

106. Peakall R, Smouse PE. GENALEX 6.5: genetic analysis in excel. population genetic software for teaching and research--an update. Bioinformatics. 2012;28:2537-9.

107. Excoffier L, Smouse PE, Quattro JM. Analysis of molecular variance inferred from metric distances among DNA haplotypes: application to human mitochondrial DNA restriction data. Genetics. 1992;131:479-91.

108. Zhang D, Gao FL, Li WX, Jakovlić I, Zou H, Zhang J, Wang GT. PhyloSuite: An integrated and scalable desktop platform for streamlined molecular sequence data management and evolutionary phylogenetics studies. Mol Ecol Resour. 2018;20:348-55.

109. Ronquist F, Teslenko M, van der Mark P, Ayres DL, Darling A, Höhna S, Larget B, Liu L, Suchard MA, Huelsenbeck JP. MrBayeS 3.2: efficient bayesian phylogenetic inference and model choice across a large model space. Syst Biol. 2012;61:539-42.

110. Li Y, Zhai SN, Qiu YX, Guo YP, Ge XJ, Comes HP. Glacial survival east and west of the 'Mekong-Salween Divide' in the Himalaya-Hengduan Mountains region as revealed by AFLPs and cpDNA sequence variation in Sinopodophyllum hexandrum (Berberidaceae). Mol Phylogenet Evol. 2011;59:412-24

111. Jian H, Tang K, Sun H. Phylogeography of Rosa soulieana (Rosaceae) in the Hengduan Mountains: refugia and 'melting' pots in the Quaternary climate oscillations. Plant Syst Evol. 2015;301:1819-30.

112. Pritchard JK, Stephens M, Donnelly P. Inference of population structure using multilocus genotype data. Genetics. 2000;155:945-59.

113. Evanno G, Regnaut S, Goudet J. Detecting the number of clusters of individuals using the software STRUCTURE: a simulation study. Mol Ecol. 2005:14:2611-20.

114. Jakobsson M, Rosenberg NA. CLUMPP: A cluster matching and permutation program for dealing with label switching and multimodality in analysis of population structure. Bioinformatics. 2007;23:1801-6.

115. Perrier X, Jacquemoud-Collet JP. DARwin software; 2006. http://darwin. cirad.fr/darwin

116. Rohlf FJ. NTSYS-pc, version 2.10. New York: Exeter Software, Setauket; 2000.

\section{Publisher's Note}

Springer Nature remains neutral with regard to jurisdictional claims in published maps and institutional affiliations.

Ready to submit your research? Choose BMC and benefit from:

- fast, convenient online submission

- thorough peer review by experienced researchers in your field

- rapid publication on acceptance

- support for research data, including large and complex data types

- gold Open Access which fosters wider collaboration and increased citations

- maximum visibility for your research: over 100M website views per year

At BMC, research is always in progress.

Learn more biomedcentral.com/submissions 